\title{
RETÓRICA DA AMEAÇA E SECURITIZAÇÃO: A política migratória dos Estados Unidos na administração Trump
}

\author{
(1) Flávio Contrera \\ Universidade Estadual Paulista (UNESP), São Paulo-SP, Brasil. \\ E-mail: flavio.contrera@unesp.br

\section{(D) Karina Lilia Pasquariello Mariano} \\ Universidade Estadual Paulista (UNESP), Araraquara-SP, Brasil. \\ E-mail: karina.mariano@unesp.br

\section{(D) Roberto Goulart Menezes} \\ Universidade de Brasília (UnB), Brasília-DF, Brasil. \\ E-mail:rgmenezes@unb.br \\ DOI: https://doi.org/10.1590/3710802/2022 \\ Para replicação dos dados, ver: DOI: https://doi.org/10.48331/scielodata.VQPTC
}

Resumo: Este artigo tem como objetivo demonstrar que as mudanças realizadas por Donald Trump na política migratória dos Estados Unidos foram conduzidas a partir da retórica da ameaça, com o propósito de securitizar a imigração. Partindo do binômio "eu-outro" para analisar discursos e ações unilaterais do Executivo, empregamos o método da Análise Crítica do Discurso $(A C D)$ para identificar as estratégias discursivas que mobilizaram o debate "nós contra eles". Em consonância com os pressupostos teóricos da Escola de Copenhague, argumentamos que Trump construiu um movimento de securitização da política migratória ao empregar uma narrativa em que latino-americanos e muçulmanos representam uma ameaça aos norte-americanos e aos Estados Unidos. Entretanto, concluímos que esse movimento foi incompleto, na medida em que não engendrou legitimação perante a maior parte da opinião pública, encontrou resistências à sua implementação no Judiciário e em governos estaduais, e não fomentou a construção de um consenso no Legislativo que resultasse em uma reforma coerente e ampla da imigração.

Palavras-chave: Estados Unidos; Imigração; Securitização; Latinos; Muçulmanos.

\section{THREAT RHETORICAND SECURITIZATION: us immigration policy in the Trump administration}

\begin{abstract}
This article aims to show that Donald Trump's changes in US migration policy were driven by threat rhetoric with the purpose of securitizing immigration. Starting from the binomial "I-other" to analyze the Executive's discourses and unilateral actions, we used the method of Critical Discourse Analysis (CDA) to identify the discursive strategies that mobilized the "us against them" debate. In line with the theoretical assumptions of the Copenhagen School, we argue that Trump built a movement to securitize migration policy by employing a narrative in which Latin Americans
\end{abstract}


and Muslims represent a threat to Americans and the United States. However, we conclude that this movement was incomplete, as it did not engender legitimacy before most of public opinion, encountered resistance to its implementation in the Judiciary and in state governments and did not foster the forging of a consensus in the Legislative that would result in a coherent and comprehensive reform of the migration policy.

Keywords: United States; Immigration; Securitization; Latinos; Muslims.

\section{Introdução}

A percepção de que a imigração representa uma ameaça à segurança nacional é um fenômeno crescente nos últimos anos. Crises de refugiados causadas por conflitos e a busca de melhores condições de vida e de trabalho têm ditado o fluxo migratório para a Europa e para os Estados Unidos. De acordo com a perspectiva teórica da securitização desenvolvida pela Escola de Copenhague, questões de segurança são construídas por meio de práticas sociais, que ocorrem primordialmente através dos discursos proferidos pelos atores interessados em estabelecer as agendas de segurança, isto é, os agentes securitizadores (Wæver, 1995). Questões políticas, como a imigração, podem sofrer processos de securitização e dessecuritização. Em teoria, qualquer questão pública pode ser securitizada, isto é, apresentada como uma ameaça existencial (Perni, 2001). Contudo, o sucesso de uma iniciativa de securitização não depende apenas do esforço dos agentes. É necessário que a questão apresentada pelo agente seja reconhecida socialmente como ameaça à segurança. Assim, para que a securitização se concretize, é necessário a ocorrência de legitimação pública (Buzan et al., 1998).

Os autores vinculados a esta perspectiva defendem que os estudos de segurança não devem se restringir às ameaças militares, mas incorporar também ameaças advindas das áreas política, econômica, ambiental e societal. Assim, o processo de securitização da imigração ocorre a partir da percepção de ameaças à ordem pública, ao mercado de trabalho e à identidade coletiva (Huysmans, 2000). Desse modo, a imigração pode ser objeto de referência para securitização nos setores militar, econômico e societal, respectivamente.

No setor militar, os objetos referentes, isto é, aqueles que podem ser percebidos como ameaça, decorrem de práticas criminosas, como delitos e tráfico de drogas, e de atos terroristas, associados aos imigrantes. No setor econômico, as ameaças advêm do impacto da imigração na economia e suas consequências para o mercado de trabalho.

No setor societal, por sua vez, os objetos de referência provêm das relações entre identidades coletivas. Essas não são predeterminadas, mas sim socialmente construídas através de processos relacionais e, portanto, estão sujeitas à mudança. A segurança societal diz respeito à capacidade de uma sociedade de persistir em seu caráter essencial sob condições variáveis e ameaças possíveis ou reais (Wæver, 1993; Buzan e Hansen, 2012). Assim, refere-se às maneiras pelas quais os membros de um Estado percebem que as características culturais, linguísticas ou religiosas de sua identidade nacional são ameaçadas pelos imigrantes.

Nesta perspectiva, é indiferente a imigração ser legal ou indocumentada, voluntária ou involuntária. Os valores que compreendem a identidade nacional do país receptor são o objeto de referência sob ameaça (Weiner, 1992). Não se trata de uma ameaça objetiva. É uma percepção subjetiva que varia em função do modo como um Estado constrói sua identidade nacional. Portanto, não é necessário que a ameaça seja real, mas que seja percebida desta forma. Em decorrência dessa subjetividade, a relação entre imigração e segurança é particularmente complexa (Choucri, 2002).

Tentativas de securitização da imigração nos EUA remontam ao Chinese Exclusion Act de 1882 (Lee, 2002) e têm se intensificado após os atentados terroristas de 11 de setembro de 2001 (Ackleson, 2005; Ghughunishvili, 2010). A concepção do imigrante como uma 
ameaça inerente, o regime amplo de deportação e a securitização da fronteira sul têm tornado a política migratória mais ou menos consistente desde então. Esses parâmetros nortearam inclusive a administração do democrata Barack Obama, abrindo caminho para o movimento de securitização da imigração promovido por Donald Trump. Todavia, Trump distingue-se em relação ao seu antecessor na medida em que intensificou a retórica contra os imigrantes indocumentados (Hutchison, 2020). Enquanto ato discursivo, nos termos da Escola de Copenhague, a retórica da ameaça advinda dos imigrantes é mobilizada pelo agente securitizador para convencer a audiência de sua gravidade. A securitização não é imposta. Para que a audiência legitime as ações emergenciais propostas pelo agente securitizador, se faz necessário o ato discursivo. É através do debate público provocado pelo ato discursivo que o objeto securitizado ganha ressonância e busca legitimidade (Buzan et al., 1998).

Ao longo da campanha eleitoral para a presidência, em 2016, Donald Trump construiu uma narrativa distorcida a respeito da globalização neoliberal, atribuindo culpabilidade a estrangeiros e imigrantes pelos indicadores de violência e criminalidade e pela deterioração dos salários e das condições de trabalho da classe trabalhadora americana. Os EUA seriam uma vítima que, por generosidade, teria permitido que imigrantes indocumentados invadissem o país e roubassem empregos (Palley, 2017). Dentro dessa narrativa, os latinoamericanos, em especial os mexicanos, ocupam um espaço relevante. Trump caracterizou os imigrantes mexicanos como criminosos, traficantes de drogas, estupradores e homens maus (Verea, 2018). Construiu também uma retórica anti-muçulmana, fundada na percepção de que o Islã promove o ódio aos americanos, apontando os muçulmanos-americanos como extremistas e terroristas (Khan et al., 2019).

No governo, em seu primeiro discurso do Estado da União, em 2018, Trump delineou os quatro pilares de sua reforma migratória: 1) oferecer um caminho de 12 anos para a obtenção de cidadania pelos dreamers; ${ }^{1}$ 2) aumentar o orçamento para a segurança nas fronteiras; 3) substituir o programa de loteria de vistos do green card, baseado na diversidade de origem do imigrante, por um programa centrado em um sistema meritocrático, privilegiando altos níveis educacionais e de riqueza; e 4) restringir a imigração baseada em laços familiares. Em face da crescente polarização partidária frente à temática da imigração, e da divisão do controle do Poder Legislativo entre democratas e republicanos, Trump não foi bem-sucedido no que concerne a promover mudanças na política migratória por legislação. Em decorrência, valeu-se de atos unilaterais do Executivo para implementar sua agenda programática e retórica.

Fazendo uso de informações extra factuais e alarmando a população sobre o potencial supostamente real das ameaças, Trump manipulou o debate político sobre imigração, distraindo sistematicamente a opinião pública, repetindo informações enganosas e normalizando soluções radicais, como a construção de um muro na fronteira com o México e a proibição da entrada de muçulmanos nos Estados Unidos (Greenhill, 2018). Ao discutir esse fenômeno pela perspectiva da Escola de Copenhague, este artigo tem como objetivo demonstrar que as mudanças realizadas por Trump na política migratória dos EUA foram conduzidas a partir da retórica da ameaça, com o intuito de securitizar a imigração.

Metodologicamente, conduzimos a Análise Crítica do Discurso de Van Dijk (2006). Através da análise de discursos e de ações unilaterais do Executivo, como executive orders e presidential proclamations, argumentamos que Trump construiu um movimento para

\footnotetext{
Os dreamers são jovens indocumentados que chegaram aos EUA com menos de 16 anos e vivem lá desde junho de 2007, continuamente. A maioria provém do México, El Salvador, Guatemala e Honduras. Os dreamers são protegidos pela política do Deferred Action for Childhood Arrivals (DACA), criada por Barack Obama em 2012. Ela concede a esses indocumentados o adiamento da deportação por um período renovável de dois anos, tornando-os elegíveis para a obtenção de uma autorização de trabalho nos EUA.
} 
securitizar a política migratória dos EUA ao criar uma narrativa na qual latino-americanos e muçulmanos representam uma ameaça aos americanos e aos Estados Unidos. Entretanto, concluímos que esse movimento foi incompleto, já que não foi capaz de engendrar legitimação perante a maior parte da opinião pública e de criar um consenso no Legislativo que resultasse em uma reforma coerente e ampla da imigração. Assim como o Legislativo, governos estaduais e locais e o Judiciário impuseram restrições à aplicação das mudanças promovidas unilateralmente por Trump na política migratória. Sujeita à descontinuidade e à incoerência decorrentes das alternâncias partidárias no Executivo, a política migratória dos Estados Unidos demanda compromisso e algum grau de consenso entre democratas e republicanos para ser reformada via legislação. Embora politizada, a questão migratória não deve mobilizar movimentos de securitização, pois estes, ao identificar o imigrante como uma ameaça, reproduzem uma retórica opressora e excludente que fomenta o ódio ao "outro", desviando o foco dos problemas mais urgentes relacionados à imigração.

A análise empreendida neste artigo divide-se em cinco seções. Na primeira, a imigração é discutida a partir da perspectiva da securitização da Escola de Copenhague. Na segunda, explicamos como o discurso da ameaça latino-americana foi mobilizado por Trump para formular políticas migratórias restritivas à imigração indocumentada, sobretudo de mexicanos e centro-americanos. Na terceira, analisamos como o discurso da ameaça terrorista foi mobilizado por Trump para promover políticas migratórias restritivas à imigração legal, sobretudo de muçulmanos. Na quarta, discutimos as perspectivas de legitimação da securitização da imigração em face da polarização ideológica que perpassava a opinião pública, os partidos políticos e o Judiciário. Na quinta, delineamos as considerações finais.

\section{A retórica da ameaça como movimento de securitização da imigração}

A retórica da ameaça é a linguagem empregada pelo chefe do Executivo para identificar e comunicar aos cidadãos as ameaças internas e externas à pátria (Jefferis, 2012). Ela é eficaz porque aumenta a persuasão do público ao invocar emoções, incentivar o processamento não racional de ideias e reforçar a identificação de um grupo (Marietta et al., 2017). A literatura de psicologia política identifica retóricas de ameaça à segurança pessoal, ao status socioeconômico dos indivíduos e ao status de grupo.

No tocante à segurança pessoal, a retórica da ameaça se refere a preocupações relacionadas à segurança física ou material (Schmid e Muldoon, 2015). A retórica da ameaça ao status socioeconômico diz respeito a uma potencial redução do bem-estar pessoal (Onreat et al., 2013), ao medo do desemprego e à percepção de que a situação econômica da família e da nação como um todo piorou (Feldman e Stenner, 1997). Finalmente, a retórica da ameaça ao status de grupo se refere à perspectiva de desintegração da identidade coletiva, sobretudo a partir de uma perspectiva simbólica que envolve visões de mundo, valores e crenças (Schmid e Muldoon, 2015; Petriglieri, 2011).

Esses três tipos de retórica podem ser associados aos movimentos de securitização da imigração em diferentes setores. O movimento de securitização da imigração no setor militar é geralmente construído a partir de uma narrativa que a relaciona à criminalidade e a representa como ameaça à ordem pública. Nos EUA, as políticas de imigração e de controle de fronteiras tornaram-se instrumentos na Guerra ao Terror (Adamson, 2006). Bush iniciou um movimento de securitização da imigração para combater o terrorismo ao incluir o Serviço de Imigração e Naturalização no então recém-criado Department of Homeland Security (Spencer, 2008). Ademais, o Patriot Act fortaleceu o controle de fronteiras, aumentando a vigilância sobre estrangeiros nos Estados Unidos e permitindo ao governo deter, processar e remover estrangeiros suspeitos de comportamento terrorista (Lebowitz e Podheiser, 2001). 
A percepção de que os imigrantes tiram empregos de cidadãos nativos e de que sua participação no mercado de trabalho deprecia os salários fundamenta a retórica da ameaça da imigração ao setor econômico (Somerville e Sumption, 2009). Essa também é alimentada pela crença de que os imigrantes sobrecarregam os serviços de educação, transporte, saneamento e comunicação (Weiner, 1992; Stivachtis, 2008). Refugiados e requerentes de asilo, particularmente, são apresentados como aproveitadores ${ }^{2}$ que exploram ilegalmente o sistema de seguridade social e bem-estar do país receptor (Huysmans, 2006).

A imigração pode ser vista como uma ameaça ao setor societal, por sua vez, quando a identidade coletiva é alterada por uma mudança na composição de sua população (Buzan et al., 1998). A identidade coletiva deriva do sentimento de que o grupo constitui uma entidade. Identidades coletivas estão geralmente organizadas na forma de tribos, clãs, religiões, civilizações e nações. A percepção da existência de ameaças exógenas tem consequências positivas na coesão de grupos sociais (Simmel, 1904; Coser, 1956) e exerce papel fundamental no processo de definição de identidades coletivas (Wendt, 1999; Buzan, 2004). Identidades coletivas são definidas a partir de processos relacionais, em oposição a um "outro". Por ser externo à identidade coletiva e, portanto, diferente dela, o "outro" representaria uma ameaça à sua existência, seja no nível material (ameaça à integridade física da nação e ao bem-estar dos indivíduos) ou simbólico (ameaça aos valores culturais da nação).

Identidades são atreladas a interesses, que orientam a formulação de políticas públicas para combater uma ameaça. Os interesses designam as motivações que ajudam a explicar o comportamento de um ator. Eles pressupõem identidades, "porque um ator não pode saber o que quer, até saber quem é"(Wendt, 1999, p. 231). Por outro lado, a inexistência ou a destruição de uma ameaça pode ter consequências negativas para a definição dos interesses de uma nação. Este caso seria ilustrado pelos Estados Unidos após o fim da Guerra Fria. O colapso do império soviético como um dominante "outro" teria gerado instabilidade na auto-concepção identitária dos EUA e, portanto, ambiguidade em seus interesses nacionais (Jepperson et al., 1996; Buzan, 2004).

Esse entendimento está presente também na ideologia conservadora dominante no Partido Republicano. Ao discutir a erosão dos interesses americanos no pós-Guerra Fria, Samuel Huntington, que é um representante deste pensamento, esclarece que a definição de interesses nacionais é precedida da definição identitária. A esse respeito, argumenta que conseguimos descobrir "quem somos" somente quando sabemos "quem não somos" e muitas vezes, "contra quem estamos" (Huntington, 1997a; 1997b).

A identidade nacional americana, explica Huntington (1997a), tem a cultura e o credo como seus dois componentes, sendo o segundo um produto do primeiro. Faria parte do universo da cultura o conjunto de valores e instituições dos imigrantes puritanos fundadores, como a língua inglesa, as tradições relativas às relações entre Igreja e Estado e o lugar do indivíduo na sociedade. O credo, por sua vez, seria composto das ideias universais e princípios articulados nos documentos originários da nação, como a liberdade, igualdade, iniciativa privada, constitucionalismo, democracia e governo limitado.

De acordo com Huntington (1997a), ambos os elementos da identidade nacional teriam sido historicamente ameaçados. A cultura, em decorrência da imigração maciça de grupos que não compartilham os valores americanos, como os latino-americanos e asiáticos. $\bigcirc$ credo, por sempre ter se constituído em contraste com um "outro" indesejável, isto é, um ator externo cujos valores diferem e, às vezes, se opõem aos valores americanos. Em

\footnotetext{
Tal perspectiva pode ser identificada no governo Trump: a Presidential Proclamation 9945, editada em 4 de outubro de 2019, determina a suspensão da entrada de imigrantes que poderiam onerar financeiramente o sistema de saúde dos Estados Unidos.
} 
diferentes momentos, a Grã-Bretanha, a Europa, o nazi-fascismo e o comunismo ocuparam o lugar do "outro" que ameaçava a identidade nacional estadunidense. A caracterização da relação entre identidades e interesses em Huntington (1997a) pode ser observada na Figura 1.

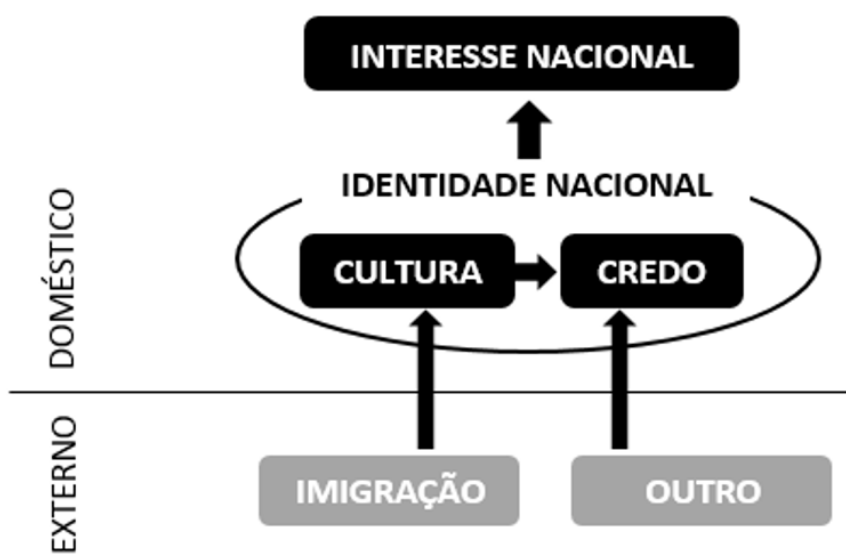

Figura 1 - Caracterização da relação entre identidades e interesses em Huntington (1997a) Fonte: elaborado pelos autores a partir de Huntington (1997a)

Conforme sustenta Huntington (1997a), a identidade nacional americana resistiu a todas aquelas ameaças. Assim, a cultura teria sido preservada através de práticas de assimilação. Na medida em que ocorria a assimilação do inglês e dos princípios do credo americano, os imigrantes eram integrados como cidadãos. A percepção da existência de uma ameaça externa, por sua vez, reforçava a coesão da identidade nacional. O interesse nacional, nesse sentido, era uma expressão homogênea de um ator coeso e unitário, orientado para a segurança e a sobrevivência da nação.

Essa situação teria se alterado no pós-Guerra Fria, momento em que interesses comerciais e étnicos teriam prevalecido em face de outros, potencialmente mais vitais à segurança nacional. A inexistência de uma ameaça externa, possibilitada pela desintegração da União Soviética, resultou em dificuldades, para os Estados Unidos, de definir seu interesse nacional. A cultura, por sua vez, era ameaçada pelo "culto ao multiculturalismo e à diversidade" promovidos nos governos de Bill Clinton (1993-2001). De acordo com Huntington (1997a), essas ideologias questionam o elemento central do credo tradicional americano, substituindo os direitos individuais pelos direitos de grupos, definidos amplamente em termos de raça, origem étnica, gênero e orientação sexual.

Em relação aos mexicanos, especificamente, Huntington (2004) constatou que eles estariam sobrecarregando as fronteiras e o mercado de trabalho nos Estados Unidos. A contínua imigração de mexicanos para o país acentuaria, em sua visão, o predomínio dos valores dos mexicanos sobre os dos mexicanos-americanos, reduzindo os incentivos à assimilação cultural. Isso ocorreria porque os mexicanos-americanos não se consideram mais membros de uma comunidade minoritária que deve se acomodar ao grupo dominante, adotando sua cultura. À medida em que a imigração aumentasse, eles se comprometeriam cada vez mais com sua própria identidade e cultura étnica. ${ }^{3}$ Havendo redução de incentivos para a assimilação do credo tradicional americano, os mexicanosamericanos passariam a vangloriar-se das diferenças entre sua cultura hispânica e a

\footnotetext{
Com base na experiência de Miami, Huntington (2004) conjectura sobre a criação de uma grande comunidade de hispânicos em estados do sudoeste dos Estados Unidos, com poder econômico e político suficientes para influenciar a política, o governo e a sociedade americana.
} 
cultura anglo-saxã. A consequência desse processo de divisão linguística e cultural seria o enfraquecimento e a instabilidade da democracia americana.

Ainda que os diagnósticos de Huntington (2004) careçam de comprovação empírica, uma vez que os imigrantes mexicanos têm sido assimilados (De la Garza et al., 1996; Waters e Jimenez, 2005; Telles, 2006; Parrado e Morgan, 2008; Vaz, 2014), eles exercem influência considerável no pensamento de agentes securitizadores e atores funcionais nos Estados Unidos, sobretudo no Partido Republicano. Com efeito, assim como os construtivistas e os teóricos da Escola de Copenhague, Huntington (1997a; 1997b) explicou a formação de interesses nacionais a partir de uma base exógena, isto é, a percepção da existência de uma ameaça vital à identidade coletiva. Contudo, o processo de securitização de uma ameaça ocorre no nível doméstico, no qual atores endógenos como a audiência, no sentido da Escola de Copenhague ou, mais especificamente, a opinião pública, a mídia, os think tanks, os grupos de interesse, os partidos políticos e os políticos no governo sustentam e legitimam concepções ideológicas que atuam sobre a construção da identidade nacional.

Conforme pontua Etzioni (2005), Huntington estaria ideologicamente vinculado à elite settler americana, que reluta em aceitar a diversidade cultural por acreditar que os imigrantes de origem diversa da dos founding fathers deveriam assimilar os valores anglo-protestantes. Enraizados na perspectiva de essencialismo cultural, os argumentos de Huntington expressam e propagam a ideologia conservadora (Capetillo-Ponce, 2007). Dominante no Partido Republicano, a ideologia conservadora fundamenta a retórica da ameaça mobilizada para securitizar a questão migratória. Na narrativa política estadunidense, os espaços destinados à representação de ameaças à cultura e ao credo são ocupados periodicamente. Os ataques terroristas de 11 de setembro de 2001 deram a George W. Bush a oportunidade de construir sua própria retórica de ameaça. Guerras no Afeganistão e no Iraque foram empreendidas para combater o terrorismo transnacional.

Partimos da premissa de que, ao vincular-se à ideologia conservadora no Partido Republicano, Donald Trump mobilizou a narrativa que entende e significa imigrantes como ameaças para construir seu próprio movimento de securitização do setor e buscar legitimá-lo. Conforme demonstraremos, a especificidade do movimento de securitização de Trump está em seu ato discursivo, construído de modo a associar imigrantes latinos, sobretudo mexicanos, e também os muçulmanos, a atividades criminosas.

\section{O método da Análise Crítica do Discurso}

Em consonância com o enfoque construtivista presente no framework da Escola de Copenhague, empregamos neste estudo a Análise Crítica do Discurso (ACD). ${ }^{4}$ Trata-se de uma abordagem analítica qualitativa, decorrente do debate pós-positivista, utilizada para descrever, interpretar e explicar criticamente as formas como os discursos constroem e legitimam as desigualdades sociais em um contexto amplo (Mullet, 2018). A ACD tem como foco as maneiras pelas quais certos eventos ou pessoas são legitimados dentro de determinadas crenças ideológicas.

Entre as múltiplas possibilidades de emprego da ACD, este estudo foi conduzido a partir do Ideological Square Model de Van Dijk (2006). Este destaca o binômio "eu-outro" e o debate "nós contra eles", cujo fundamento é a auto-representação positiva, concomitante à representação negativa do "outro", com o propósito de reforçar crenças, práticas e

\footnotetext{
4 Se, por um lado, os trabalhos de Ole Wæver (1993; 1995) desenvolveram uma análise construtivista de segurança na Escola de Copenhague, de forma complementar Balzacq (2011, p. 40) indica, em análise epistemológica, que o uso da análise do discurso pela perspectiva da securitização conforma-se, ainda que tacitamente, à tradição da análise crítica do discurso.
} 
sentimentos ideológicos. Como vimos na seção anterior, tal debate também fomenta a construção de identidades coletivas na perspectiva construtivista de Copenhague e na perspectiva conservadora de Samuel Huntington. Dessa forma, esta ferramenta analítica apresenta-se como adequada, do ponto de vista epistemológico, para explorar e destacar a polarização de "nós" contra "eles", na qual o enunciador e seus aliados são considerados "nós", enquanto os oponentes são colocados na categoria "eles" (Van Dijk, 2006).

O Ideological Square Model consiste em uma macro-análise e uma micro-análise. A macro-análise dispõe de quatro estratégias:

1) Enfatizar aspectos positivos sobre "nós".

2) Enfatizar aspectos negativos sobre "eles".

3) Minimizar aspectos negativos sobre "nós".

4) Minimizar aspectos positivos sobre "eles".

A microanálise, por sua vez, consiste em 25 estratégias discursivas retóricas, descritas no Quadro 1.

\section{QUADRO 1 - Estratégias discursivas retóricas}

\begin{tabular}{|c|c|}
\hline Estratégia & Significado e aplicação \\
\hline Descrição do ator & $\begin{array}{l}\text { Fornece informações detalhadas sobre uma entidade, pessoa, lugar ou } \\
\text { coisa, e sobre a maneira como essa entidade desempenha seu papel, em } \\
\text { um contexto social ou político, de forma positiva ou negativa. Como tal, os } \\
\text { membros do grupo interno tendem a ser descritos de forma positiva ou } \\
\text { neutra, e os membros externos, ao mesmo tempo, de maneira negativa. }\end{array}$ \\
\hline Autoridade & $\begin{array}{l}\text { Mencionar autoridades para apoiar a afirmação de alguém em uma } \\
\text { declaração. Essas autoridades são: organizações, pessoas consideradas } \\
\text { líderes morais e especialistas, organizações internacionais, acadêmicos, } \\
\text { mídia, igreja ou tribunais. }\end{array}$ \\
\hline Custo & $\begin{array}{l}\text { Refere-se à perda humana ou financeira de um grupo específico. } \\
\text { Empregado para tocar os sentimentos do público-alvo. }\end{array}$ \\
\hline Categorização & $\begin{array}{l}\text { Significa atribuir pessoas a grupos diferentes. É aplicado para classificar as } \\
\text { pessoas em relação a suas opiniões e seus atos. }\end{array}$ \\
\hline Comparação & $\begin{array}{l}\text { Significa determinar as semelhanças e diferenças entre duas entidades, } \\
\text { empregando características positivas dos membros do grupo do } \\
\text { enunciador e negativas dos membros do grupo externo. }\end{array}$ \\
\hline Consenso & $\begin{array}{l}\text { O consenso costuma ser estabelecido para fomentar e construir } \\
\text { solidariedade e acordo. É um dispositivo para defender um país contra } \\
\text { ameaças externas ou qualquer questão nacional. }\end{array}$ \\
\hline Contra-factual & $\begin{array}{l}\text { É uma estratégia argumentativa persuasiva usada para o movimento de } \\
\text { pedir empatia ou uma expressão para destacar o que algo ou alguém seria } \\
\text { como se certas condições fossem criadas ou não criadas. }\end{array}$ \\
\hline $\begin{array}{l}\text { Isenção de } \\
\text { responsabilidade }\end{array}$ & $\begin{array}{l}\text { É uma estratégia de base ideológica que determina atributos positivos } \\
\text { de uma entidade e, em seguida, apresenta uma negação dos atributos } \\
\text { usando termos como mas, ainda ou entretanto. }\end{array}$ \\
\hline Eufemismo & $\begin{array}{l}\text { É uma tática comunicativa em que o locutor tenta usar palavras mais } \\
\text { suaves ou menos ásperas em lugar de termos depreciativos ou diretos. } \\
\text { Utilizado para mitigar a formação de impressões ou atos negativos do } \\
\text { próprio grupo. }\end{array}$ \\
\hline Evidencialidade & $\begin{array}{l}\text { É o emprego de fatos reais e números para apoiar a afirmação ou ideia } \\
\text { do locutor. Esta estratégia é usada para fornecer fatos por um produtor } \\
\text { de discurso, a fim de apoiar suas próprias crenças e opiniões e transmitir } \\
\text { objetividade, confiabilidade, validade e, portanto, credibilidade. }\end{array}$ \\
\hline Ilustração & $\begin{array}{l}\text { É uma estratégia comunicativa usada por quem fala para apresentar } \\
\text { exemplos factuais, apropriados ou fictícios, a fim de tornar sua declaração } \\
\text { mais concebível. }\end{array}$ \\
\hline Generalização & É uma tática usada para atribuir aspectos negativos e positivos a atores. \\
\hline Hipérbole & Estratégia linguística que diz respeito ao exagero da linguagem. \\
\hline
\end{tabular}


QUADRO 1 - Continuação...

\begin{tabular}{l|l}
\hline \multicolumn{1}{c|}{ Estratégia } & \multicolumn{1}{c}{ Significado e aplicação } \\
\hline Implicação & $\begin{array}{l}\text { Refere-se ao entendimento sobre o que não está explicitamente expresso } \\
\text { no discurso, seja no texto ou na fala. Ao usar essa tática, quem fala sempre } \\
\text { tenta deduzir informações. }\end{array}$ \\
\hline Ironia & $\begin{array}{l}\text { Se refere à dissimilaridade deliberada entre o que é dito e o que o } \\
\text { produtor do discurso pretende transmitir por meio do uso da linguagem. }\end{array}$ \\
\hline Lexicalização & $\begin{array}{l}\text { O uso de características semânticas das palavras para retratar algo ou } \\
\text { alguém positiva ou negativamente. }\end{array}$ \\
\hline Metáfora & $\begin{array}{l}\text { Contraste ou comparação de dois fenômenos ou coisas que não têm } \\
\text { semelhança para atribuir a um os atributos do outro. }\end{array}$ \\
\hline nutoglorificação & $\begin{array}{l}\text { Representação positiva de um país específico por meio de certas } \\
\text { referências positivas, como história, princípios, cultura e tradições. }\end{array}$ \\
\hline Expressão & $\begin{array}{l}\text { Refere-se a transmitir as normas de como algo deve ou não ser feito e o } \\
\text { que alguém deve ou não fazer. }\end{array}$ \\
\hline normativa & $\begin{array}{l}\text { Estratégia que ajuda o locutor a gerar autenticidade e credibilidade por } \\
\text { meio de números e estatísticas. }\end{array}$ \\
\hline Polarização de números & $\begin{array}{l}\text { Categorização das pessoas de dentro do grupo e seus aliados com } \\
\text { características positivas e das pessoas de fora do grupo com características } \\
\text { negativas. }\end{array}$ \\
\hline Populismo & $\begin{array}{l}\text { Estratégia política em que o orador ou líder político deseja ganhar cada } \\
\text { vez mais popularidade ao colocar suas ideias e políticas. }\end{array}$ \\
\hline Pressuposto & $\begin{array}{l}\text { É uma suposição implícita sobre o mundo e uma estratégia política } \\
\text { importante na qual quem fala usa a linguagem para atingir seus objetivos } \\
\text { políticos, sem qualquer evidência ou prova. }\end{array}$ \\
\hline $\begin{array}{l}\text { O uso, pelo produtor de discurso, de linguagem que cria "incerteza e } \\
\text { ambiguidade", ao falar de questões polêmicas, como imigração, segurança } \\
\text { etc. }\end{array}$ & $\begin{array}{l}\text { Estratégia para retratar os membros do grupo interno como vítimas de } \\
\text { todos os contratempos ou tratamentos injustos causados pelos membros } \\
\text { do grupo externo. }\end{array}$ \\
\hline Fonte: adaptado de Khan et al. (2019) e Van Dijk (2006). \\
\hline Vague
\end{tabular}

Considerando que o movimento de securitização de um setor se inicia a partir de um ato discursivo (Buzan et al., 1998), analisamos nas seções 2 e 3 sequências discursivas (SD) de Trump enquanto candidato e como presidente, coletadas em discursos e tweets disponíveis no banco de dados do American Presidency Project, conforme o Quadro 2.

QUADRO 2 - Discursos analisados

\begin{tabular}{c|l|l}
\hline \multicolumn{1}{c|}{ Data } & \multicolumn{1}{c}{ Discurso } & \multicolumn{1}{c}{ SDs } \\
\hline 16 de junho de 2015 & $\begin{array}{l}\text { Remarks Announcing Candidacy for President in } \\
\text { New York City }\end{array}$ & SD1, SD2 \\
\hline 02 de janeiro de 2019 & Tweet, às 13h35 ET & SD3 \\
\hline 13 de junho de 2016 & $\begin{array}{l}\text { Remarks at Saint Anselm College in Manchester, } \\
\text { New Hampshire }\end{array}$ & SD4, SD5, SD6 \\
\hline 12 de junho de 2016 & Tweet, às 17h47 ET & SD7 \\
\hline 20 de janeiro de 2017 & Inaugural Address & SD8 \\
\hline
\end{tabular}

Fonte: elaborado pelos autores.

Partindo da perspectiva teórica da Escola de Copenhague, entendemos que é necessário que o agente securitizador chame a atenção da audiência para o objeto nos termos construídos, e que seu discurso ganhe ressonância suficiente para que o movimento de securitização de um setor seja legitimado (Buzan et al., 1998). Assim, ao selecionar as SD que constituem o corpus de nossa análise, priorizamos discursos proferidos em momentos 
importantes de mobilização da audiência na trajetória política de Trump, como o anúncio de sua candidatura, o ataque terrorista de San Bernardino e a posse como presidente.

De acordo com Orlandi (2012), em Análise do Discurso a delimitação do corpus não segue critérios empíricos, mas sim teóricos. Nessa forma de análise não se objetiva a exaustividade horizontal, nem a completude ou a exaustividade em relação ao objeto empírico. Isto porque não há um discurso fechado em si mesmo, mas um processo discursivo a partir do qual é possível recortar e analisar estados diferentes. De fato, a exaustividade almejada é a vertical, que deve ser considerada em relação aos objetivos da análise e sua temática:

\footnotetext{
Assim, a construção do corpus e a análise estão intimamente ligadas: decidir o que faz parte do corpus já é decidir acerca de propriedades discursivas. Atualmente, considera-se que a melhor maneira de atender à questão da constituição do corpus é construir montagens discursivas que obedeçam a critérios que decorrem de princípios teóricos de análise de discurso face aos objetivos da análise, e que permitam chegar à sua compreensão. Esses objetivos, em consonância com o método e os procedimentos, não visa a demonstração, mas a mostrar como um discurso funciona produzindo (efeitos de) sentidos. (Orlandi, 2012, p. 63)
}

Nesse sentido, as SD incluídas no corpus desta análise tanto decorrem de princípios teóricos como se coadunam com os objetivos da análise, pois são capazes de produzir efeitos de sentido que explicam a securitização da imigração a partir da retórica da ameaça. Delimitado o corpus nos termos delineados pela Escola de Copenhague, e também por Orlandi (2012), analisamos posteriormente as ações políticas propriamente ditas. Isto é, as executive orders (E.O.) e as presidential proclamations (P.P.) $)^{5}$ emitidas por Trump para securitizar a imigração. Nesse aspecto, o foco foi esclarecer a natureza desses dispositivos de securitização e as políticas geradas por eles em face dos atos discursivos prévios. Ao longo de seu mandato, Trump emitiu um total de 220 E.O. e 570 P.P. Analisando-as individualmente, identificamos seis E.O. e nove P.P. que tratam da temática da imigração latino-americana e muçulmana. Não incluíamos no corpus medidas unilaterais sobre imigração não relacionadas ao objeto. Esse conjunto de documentos também foi coletado no banco de dados do American Presidency Project, conforme o Quadro 3.

QUADRO 3 - Executive Orders e Presidential Proclamations analisadas

\begin{tabular}{|c|c|c|}
\hline Data & Ação & Título \\
\hline 25 de janeiro de 2017 & E.O. 13767 & $\begin{array}{l}\text { Border Security and Immigration Enforcement } \\
\text { Improvements }\end{array}$ \\
\hline 25 de janeiro de 2017 & E.O. 13768 & $\begin{array}{l}\text { Enhancing Public Safety in the Interior of the } \\
\text { United States }\end{array}$ \\
\hline 27 de janeiro de 2017 & E.O. 13769 & $\begin{array}{l}\text { Protecting the Nation from Foreign Terrorist Entry } \\
\text { into the United States }\end{array}$ \\
\hline 06 de março de 2017 & E.O. 13780 & $\begin{array}{l}\text { Protecting The Nation From Foreign Terrorist Entry } \\
\text { Into The United States }\end{array}$ \\
\hline 18 de abril de 2017 & E.O. 13788 & Buy American and Hire American \\
\hline 20 de junho de 2018 & E.O. 13841 & $\begin{array}{l}\text { Affording Congress an Opportunity to Address } \\
\text { Family Separation }\end{array}$ \\
\hline 24 de setembro de 2017 & P.P. 9645 & $\begin{array}{l}\text { Enhancing Vetting Capabilities and Processes for } \\
\text { Detecting Attempted Entry Into the United States } \\
\text { by Terrorists or Other Public-Safety Threats }\end{array}$ \\
\hline
\end{tabular}

\footnotetext{
As executive orders, assim como as presidential proclamations constituem um tipo específico de ato presidencial comum a diversas democracias contemporâneas. Permitem ao Executivo promulgar medidas de caráter legislativo, para implementar leis e administrar o Estado. Trata-se de uma capacidade formal do presidente de agir unilateralmente e, assim, fazer leis por conta própria (Moe e Howell, 1999), inclusive contornando maiorias legislativas ideologicamente hostis (Martin, 1999).
} 
QUADRO 3 - Continuação...

\begin{tabular}{|c|c|c|}
\hline Data & Ação & Título \\
\hline 10 de abril de 2018 & P.P. 9723 & $\begin{array}{l}\text { Maintaining Enhanced Vetting Capabilities and } \\
\text { Processes for Detecting Attempted Entry Into the } \\
\text { United States by Terrorists or Other Public-Safety } \\
\text { Threats }\end{array}$ \\
\hline 09 de novembro de 2018 & P.P. 9822 & $\begin{array}{l}\text { Addressing Mass Migration Through the Southern } \\
\text { Border of the United States }\end{array}$ \\
\hline 07 de fevereiro de 2019 & P.P. 9842 & $\begin{array}{l}\text { Addressing Mass Migration Through the Southern } \\
\text { Border of the United States }\end{array}$ \\
\hline 15 de fevereiro de 2019 & P.P. 9844 & $\begin{array}{l}\text { Declaring a National Emergency Concerning the } \\
\text { Southern Border of the United States }\end{array}$ \\
\hline 08 de maio de 2019 & P.P. 9880 & $\begin{array}{l}\text { Addressing Mass Migration Through the Southern } \\
\text { Border of the United States }\end{array}$ \\
\hline 25 de setembro de 2019 & P.P. 9931 & $\begin{array}{l}\text { Suspension of Entry as Immigrants and } \\
\text { Nonimmigrants of Persons Responsible for Policies } \\
\text { or Actions That Threaten Venezuela's Democratic } \\
\text { Institutions }\end{array}$ \\
\hline 25 de setembro de 2019 & P.P. 9932 & $\begin{array}{l}\text { Suspension of Entry as Immigrants and } \\
\text { Nonimmigrants of Senior Officials of the } \\
\text { Government of Iran }\end{array}$ \\
\hline 31 de janeiro de 2020 & P.P. 9983 & $\begin{array}{l}\text { Improving Enhanced Vetting Capabilities and } \\
\text { Processes for Detecting Attempted Entry Into the } \\
\text { United States by Terrorists or Other Public-Safety } \\
\text { Threats }\end{array}$ \\
\hline
\end{tabular}

Fonte: elaborado pelos autores.

Na medida em que a securitização não é imposta pelo agente e que sua legitimação repousa na audiência (Buzan et al., 1998), para verificar se o movimento de securitização iniciado por Trump foi legitimado, analisamos na seção 4 as ações tomadas pelos governos estaduais, pelo Legislativo e pela Suprema Corte em relação aos dispositivos de securitização empregados. Avaliamos também o convencimento da audiência em relação aos atos discursivos e aos dispositivos, através da análise de resultados de pesquisas de opinião pública coletados no tópico Immigration/Border Security do PollingReport. com no período 2017-2020. Como indicam Meynaud e Duclos (2007), as pesquisas de opinião pública são, ao mesmo tempo, processos e resultados. Em outras palavras, os resultados das pesquisas podem ser instrumentalizados e ter um papel nos movimentos de securitização, mas também podem ser utilizados para contabilizar casos (bem-sucedidos) de securitização.

Nas seções seguintes discutiremos as políticas migratórias implementadas por Trump em face da retórica da ameaça latino-americana e muçulmana.

\section{O movimento de securitização da imigração latino-americana}

Como todos os demais países do continente americano, os Estados Unidos resultaram de um processo colonizador. Esse fato representa uma questão ideológica importante na construção da identidade nacional: em primeiro lugar, a identificação com os peregrinos que, enquanto grupo étnico, deram origem aos founding fathers, originários de nações do Reino Unido, brancos e protestantes; e com os pioneiros que garantiram a expansão territorial e também pertenciam à mesma etnia. Apesar da presença de indígenas e escravos, as concepções da elite política, no início da história estadunidense, estão marcadas pela percepção de uma certa homogeneidade cultural.

Essa percepção modelou a política imigratória do país, que, ao longo de sua existência, buscou estimular a entrada de estrangeiros etnicamente "adequados", mas também de 
interesse socioeconômico (Koudela, 2013). Desde a Lei de Naturalização de 1790 até a Lei de Imigração de 1990, houve estímulo à vinda de europeus ocidentais com bom nível de escolaridade, protestantes e considerados economicamente capazes. Por outro lado, foram crescentes as barreiras para a entrada de estrangeiros considerados não-arianos, católicos e/ou muçulmanos, iletrados, deficientes, inadequados e ideologicamente indesejáveis (comunistas, principalmente).

As restrições aos imigrantes variaram conforme os momentos, e como forma de reação à intensidade dos fluxos de determinados grupos indesejados, como os irlandeses e os chineses em meados do século XIX, os russos a partir de 1880 e os japoneses, europeus mediterrâneos e do Leste ao longo da primeira metade do século XX (Koudela, 2013), e assim por diante. Somente com as mudanças introduzidas a partir de 1990 essa lógica de exclusão perdeu força, prevalecendo uma percepção de estímulo à diversidade na aceitação de imigrantes pela nova Lei Migratória.

O discurso e o comportamento do ex-presidente Trump no sentido de securitizar a questão da imigração não deixa de ser uma tentativa de reativar os antigos preconceitos que estavam internalizados na construção das leis migratórias estadunidenses originais, que buscavam garantir a homogeneidade étnica e cultural diante da percepção de que a diversidade populacional poderia erodir o modelo de nação construído, colocando em risco a identidade nacional.

Neste caso, não é possível ressuscitar formalmente preconceitos em relação a determinados grupos de imigrantes baseando-se simplesmente na diversidade cultural, algo que a lógica da globalização ressalta como um aspecto positivo, mas sim associando esses grupos a ameaças concretas, capazes de mobilizar a sociedade na defesa contra um inimigo comum. Portanto, a construção do discurso anti-imigrante se fundamenta em três pilares: antiglobalização, violência e proximidade.

Com efeito, a retórica discursiva do governo Trump está fundamentada na identificação da globalização neoliberal como o fenômeno causal dos problemas enfrentados pelo país, especialmente no aspecto econômico. Desta forma, o desemprego não seria consequência apenas do deslocamento produtivo e de investimentos decorrentes da competição injusta promovida pelos parceiros comerciais dos EUA, mas também do estímulo crescente à imigração que, segundo essa argumentação, rouba os postos de trabalho americanos. No lançamento de sua campanha à presidência, em junho de 2015, Trump declarou:

SD1 [Estratégia discursiva]

1. When do we beat Mexico at the border? [Ilustração]

2. They're laughing at us, at our stupidity. [Hipérbole e Vitimização]

3. And now they are beating us economically. [Vitimização e Vagueza]

4. They are not our friend, [Polarização]

5. believe me. [Pressuposto]

6. But they're killing us economically. [Vitimização, Hipérbole e Vagueza]

Identifica-se na SD1 a diferenciação entre "nós" (Estados Unidos, apresentado como we, us e our) e eles (México, they). Ao invocar a primeira pessoa do plural, Trump posiciona-se no mesmo lugar de sua audiência. Do ponto de vista da macro-análise, o aspecto mais significativo é que Trump enfatiza aspectos negativos sobre "nós". Trata-se de uma estratégia não delineada no modelo de Van Dijk (2006), mas racional no contexto eleitoral, visto que Trump, como candidato, apresentava-se como a única liderança capaz de reverter a suposta derrota econômica imposta pelo México aos EUA. Com efeito, Trump retratou os EUA a partir de uma vaga vitimização e utilizou como estratégias discursivas, para caracterizar "eles", a ilustração, hipérbole e polarização. O México foi apresentado como um competidor econômico que estaria superando e zombando dos EUA. Em seguida, 
Trump, utilizando-se de pressuposto, buscou convencer a audiência de que o México não é um aliado dos EUA. Finalmente, ao afirmar they're killing us economically, Trump converteu o então competidor em uma ameaça.

Mais do que construir a percepção de que o México, enquanto Estado, constitui uma ameaça, no mesmo discurso Trump associou os imigrantes mexicanos à violência crescente e presente no cotidiano dos EUA, conforme a SD2:

SD2 [Estratégia discursiva]

1. When Mexico sends its people, they're not sending their best. [Categorização e Generalização]

2. They're not sending you. They're not sending you. [Comparação]

3. They're sending people that have lots of problems. [Comparação, Categorização e Generalização]

4. and they're bringing those problems with us. They're bringing drugs. They're bringing crime. They're rapists. [Categorização e Generalização]

5. And some, I assume, are good people. [Pressuposto e Categorização]

6. But I speak to border guards and they tell us what we're getting. [Ilustração e Autoridade]

7. And it only makes common sense. It only makes common sense. [Evidencialidade]

8. They're sending us not the right people. [Categorização e Generalização]

9. It's coming from more than Mexico. It's coming from all over South and Latin America, and it's coming probably - probably - from the Middle East. [Ilustração]

10. But we don't know. [Contrafactual]

11. Because we have no protection and we have no competence, we don't know what's happening. [Vitimização]

12. And it's got to stop and it's got to stop fast". [Expressão normativa]

A diferenciação entre "nós" e "eles" também está presente na SD2. Fazendo uso de estereótipos, Trump categorizou e generalizou o comportamento do imigrante mexicano, identificando-o como uma ameaça. A SD2 exemplifica a identificação do inimigo como próximo: os mexicanos, que na verdade simbolizam os latino-americanos em geral, são identificados como promotores do incremento da criminalidade e da violência na sociedade estadunidense (Marietta et al., 2017). Os EUA, em contraste, são caracterizados como vitimizados: desprotegidos, incompetentes e desinformados. Para conferir validade a seu discurso, Trump recorreu à autoridade dos guardas da fronteira. Finalmente, Trump expressou sua proposta, a de que essa situação teria de ser interrompida rapidamente.

Enquanto grupo étnico com crescente participação na população americana, os mexicanos convertem-se, no plano discursivo, em ameaça identitária. Apesar disso, eles não estão distribuídos territorialmente de forma homogênea. Mas, à guisa de exemplo, é interessante apontar que, em 1940, essa população representava apenas $6 \%$ dos habitantes do estado da Califórnia, ao passo que, em 2010, chegava a 37,6\% (Koudela, 2013). Cria-se no imaginário da opinião pública a percepção de que a ameaça está presente em seu cotidiano e que, de alguma forma, foi o posicionamento amigável do governo em relação aos imigrantes que permitiu isso, ou seja, a legislação de 1990, tão atacada pela administração Trump.

Marietta et al. (2017) apontam que o discurso radicalizado do presidente Trump, sustentado pela lógica da ameaça, foi eficiente para promover uma mobilização de sustentação ao governo e à sua estratégia de securitizar a questão da imigração, porque construiu um inimigo claro: o imigrante como agente da violência física e contra o bemestar dos cidadãos (ao tirar-lhes o emprego), mas, acima de tudo, destruidor da identidade nacional. Esse inimigo estava difuso desde o final da Guerra Fria, quando a extinta União Soviética deixou de ser uma ameaça à segurança nacional norte-americana. 
Esse discurso radicalizado também pressupõe a construção de uma imagem perante a opinião pública: de que o político age movido por princípios, de que há uma lógica intransigente que o mobiliza, e de que suas ações não se intimidam diante de impedimentos legais, porque são promovidas pelo voluntarismo que permite a ele ir além das convenções tradicionais. Esse comportamento fica claro em relação ao tratamento dado à China, mas ainda mais especialmente ao México.

O caso mexicano é particularmente explorado por algumas razões: em primeiro lugar, pela interdependência econômica existente entre os dois países, e a clara dependência mexicana em relação à economia norte-americana, o que limita a capacidade de resistência e retaliação de seu governo às ameaças da administração Trump; pela representação simbólica, pois os imigrantes latino-americanos (especialmente os centro-americanos) acabam sendo identificados como mexicanos, expandindo a dimensão da ameaça; e, finalmente, pela proximidade física que permite identificar claramente o inimigo e, ao mesmo tempo, evidenciar o combate a ele, como no caso da construção do muro na fronteira. Este último aspecto pode ser entendido como central, já que, de todos os inimigos construídos pelo discurso do presidente Trump, é somente contra os imigrantes indocumentados que é possível erguer uma barreira de combate, algo visível para a opinião pública. No caso das demais ameaças, são medidas legais ou econômicas cuja efetividade é mais sutil e difusamente perceptível.

O combate à violência e à insegurança causadas pelo México não só se materializa na construção do muro como está presente na retórica do presidente estadunidense de que esse combate é imposto ao próprio agressor, que deveria arcar com os custos desse muro. Em 2 de janeiro de 2019, o presidente Trump chegou a afirmar, numa postagem no Twitter:

SD3 [Estratégia discursiva]

1. Mexico is paying for the Wall through the new USMCA Trade Deal. [Evidencialidade]

2. Much of the Wall has already been fully renovated or built. We have done a lot of work. [Evidencialidade]

3. $\$ 5.6$ billion dollars that House has approved is very little in comparison to the benefits of National Security. [Jogo de números e Vagueza]

4. Quick payback! [Ironia]

Do ponto de vista factual, a SD3 chama a atenção, porque o acordo, que substituiu o North American Free Trade Agreement (NAFTA), ainda não havia sido ratificado pelos congressos nacionais e, portanto, o United States-Mexico-Canada Agreement(USMCA) não estava em vigor. ${ }^{6}$ Além disso, não há garantias de que os ganhos em relação ao México, com a implementação do acordo, sejam suficientes para compensar no curto prazo os custos estimados em 25 bilhões de dólares ${ }^{7}$ para a construção do muro na fronteira entre os dois países. Trump buscou conferir veracidade ao seu discurso empregando evidencialidade, jogo de números e vagueza. Com efeito, esta sequência discursiva revela uma mudança na narrativa de construção dos atores: agora como presidente, Trump enfatiza aspectos positivos sobre "nós". Se, partindo da análise interna ao discurso, pode-se verificar que o EUA impôs, com o acordo do USMCA, uma derrota ao México (que estaria pagando pelo muro), do ponto de vista da análise externa destaca-se que o México, enfim superado, não estaria mais rindo da estupidez dos EUA, como mencionado na SD1. Para salientar esta percepção, Trump ironicamente manifesta que seu governo revidou rapidamente a situação anterior.

O USMCA entrou em vigor apenas em $1^{\circ}$ de julho de 2020.

Disponível em https://www.bbc.com/news/world-us-canada-37243269. Acesso em: 28/06/2021. 
A radicalização do discurso presidencial em relação aos imigrantes mexicanos/latinos não se expressa somente na criação de uma barreira física, mas também no comportamento, em um combate ostensivo na região fronteiriça (com a presença de uma vigilância massiva e agressiva), nos maus tratos recebidos pelos imigrantes ilegais capturados e na política de separação das famílias. Nesse sentido, Trump buscou no governo securitizar a imigração latino-americana a partir da edição de executive orders e presidential proclamations e do encerramento de programas de proteção a imigrantes indocumentados, atos que endureceram a política migratória.

A aversão de Trump aos imigrantes marcou sua gestão desde o início. Como assinala Armendares (2018, p. 43, tradução nossa), "quando Trump chegou à Casa Branca, ele herdou a 'máquina de deportação' construída por Bush e Obama, e não demoraria muito para fortalecê-la". Segundo ele, o governo Trump buscava subverter o consenso predominante de que o resultado da imigração é positivo para a economia e a sociedade norte-americanas. Estima-se que apenas com o fim do DACA, os EUA deixariam de arrecadar 4 bilhões de dólares em impostos anualmente; o governo federal perderia outros 60 bilhões, e a economia do país encolheria 280 bilhões de dólares (Filomeno, 2020).

A "máquina de deportação" foi colocada para funcionar a pleno vapor desde o início da gestão Trump. A determinação da construção de um muro na fronteira dos Estados Unidos com o México foi assinada em 25 de janeiro de 2017, pela Executive Order 13767. Nela, o governo Trump também ordena que as autoridades migratórias assegurem a fronteira e deportem, em rito sumário, os imigrantes indocumentados que tentarem cruzá-la. Na mesma data, o presidente assinou outra executive order, a 13768, intitulada Enhancing Public Safety in the Interior of the United States, que aumentou significativamente o número de imigrantes considerados prioritários para deportação, em decorrência de acusações criminais, e ordenou que cidades-santuário não estariam aptas a receber subsídios federais exceto em casos considerados necessários para fins de aplicação da lei. Esta última medida foi considerada inconstitucional, em 21 de novembro de 2017, pelo juiz William Orrick III.

Com a Executive Order13768, pode ser deportada qualquer pessoa que represente, no juízo de um agente de imigração, algum risco para a segurança pública e a segurança nacional (Armendares, 2018). Além disso, a ordem retoma o programa Secure Communities (S-Comm), criado no fim do segundo mandato de George W. Bush (2001-2009). Esse programa está a cargo do Immigration and Customs Enforcement(ICE). Quando uma pessoa é detida, suas digitais são inseridas no sistema do ICE. Imigrantes não documentados, legais e residentes permanentes podem ser deportados em caso de detenção e registro em prisão (inclusive por violência doméstica), mesmo sem ter sido condenados.

Esse polêmico programa foi suspenso por Obama somente em 2014. As principais críticas ao S-Comm é que ele violava os direitos civis, além de se estender a todas as pessoas que estivessem dentro da residência do indocumentado no momento de uma ação do ICE. De acordo com os dados disponíveis sobre o ano de 2017, das 43.000 pessoas deportadas pelo programa, apenas cerca de $10 \%$ haviam sido sentenciadas por delitos graves. Entre 2008 e 2018, 363.400 pessoas foram deportadas, a grande maioria oriundas do México e da América Central.

Em abril de 2017, o presidente Donald Trump emitiu a Executive Order 13788, intitulada Buy American and Hire American, cujo objetivo era direcionar os departamentos federais relevantes para elaborar políticas que incentivassem a compra de produtos fabricados nos Estados Unidos e a contratação de trabalhadores nascidos nos EUA. Com relação às leis e às políticas de imigração, o foco da ordem era formular e implementar mecanismos para assegurar que os componentes das leis de imigração fossem rigorosamente cumpridos, no intuito de proteger o emprego, as condições de trabalho e os salários dos trabalhadores estadunidenses.

Para lidar com a imigração maciça de centro-americanos que cruzavam o México em direção aos Estados Unidos, o presidente Trump emitiu, em 9 de novembro de 2018, a 
Presidential Proclamation 9822, intitulada Addressing Mass Migration Through the Southern Border of the United States. Essa proclamação suspendeu o direito de asilo de qualquer migrante que cruzasse a fronteira EUA-México fora de um porto de entrada legal. Tal medida foi renovada por noventa dias em 7 de fevereiro de 2019, pela P.P. 9842, e em 8 de maio de 2019, pela P.P. 9880. No dia 15 de fevereiro de 2019, a P.P. 9844, Declaring a National Emergency Concerning the Southern Border of the United States, determinou o uso das forças armadas para lidar com a emergência humanitária na fronteira sul. No âmbito das políticas de imigração relacionadas à proteção humanitária, Trump também encerrou os benefícios do Temporary Protected Status(TPS), ${ }^{8}$ que se estendiam a 437.000 imigrantes, a maioria deles da América Central e do Caribe.

O governo Trump investiu contra a política migratória dos Estados Unidos também ao tentar acabar com o programa Deferred Action for Childhood Arrivals (DACA). Criado na primeira gestão do ex-presidente Obama, em 2012, o DACA protege, atualmente, cerca de 910 mil pessoas que foram levadas ainda crianças para os EUA de forma ilegal. Dominado pelos republicanos, o Congresso não apoiou a lei DREAM (Development, Relief and Education for Alien Minors Act), proposta pela gestão Obama. Diante desse bloqueio à reforma da lei de imigração, Obama emitiu uma executive orderinstituindo o DACA. O programa protege menores de idade de serem deportados do país e concede a eles um visto temporário de dois anos, renovável. Para obter esse visto é preciso cumprir regras bem rígidas, além de pagar uma taxa de 495 dólares. O objetivo da reforma da lei de imigração proposta por Obama era legalizar a situação de milhões de imigrantes.

Desde sua criação, o DACA sofreu severas críticas do espectro conservador da sociedade estadunidense. Embora o programa não conceda a cidadania automática e nem mesmo assegure que ela será reconhecida no futuro - ele tampouco garante residência permanente -, a proteção temporária que dá às crianças em situação irregular atraiu a ira do eleitorado republicano em especial. Trump aproveitou-se dessa insatisfação com a "política de fronteiras abertas" e escolheu o DACA como um de seus alvos durante a campanha eleitoral. Sua promessa de acabar com o programa foi cumprida em 5 de setembro de 2017, com o ato unilateral do Department of Homeland Security. Embora a Suprema Corte tenha anulado a decisão presidencial e mantido o DACA em vigor, enquanto foi presidente Trump não desistiu de encerrar o programa. Paradoxalmente, o argumento da gestão Trump para acabar com o DACA era de que ele havia sido instituído por uma executive ordere, portanto, teria extrapolado a competência do Executivo para legislar sobre a imigração (Filomeno, 2020).

Em sua grande maioria, os dreamers - imigrantes que chegaram aos EUA ainda crianças e são protegidos pelo DACA - nasceram no México e em países da América Central. Entre 2013 e 2018, o afluxo de imigrantes vindos da América Central seguiu intenso e "cerca de 875.000 hondurenhos, salvadorenhos e guatemaltecos chegaram à fronteira com os EUA" (Leutert, 2018). Um ano após Trump decretar o fim do "sonho americano" para milhares de crianças, imagens das marchas de mulheres, crianças e jovens saídos da América Central com destino à fronteira México/Estados Unidos exibidas pelas redes de televisão aumentaram a sensação de "ameaça". O presidente Trump classificou a onda como uma invasão aos EUA e deslocou cerca de 5.200 soldados para a fronteira sul. E, em janeiro de 2019, Trump criou o programa Remain in Mexico, determinando que imigrantes indocumentados, detidos na fronteira com o México, fiquem nesse país até que o pedido de asilo seja avaliado. Somente em 2019, quase um milhão de pessoas foram detidas, e a grande maioria delas era de Honduras, El Salvador e Guatemala.

O Congresso criou o TPS sob a Lei de Imigração de 1990, como forma de proteção humanitária temporária a estrangeiros que estão nos Estados Unidos e não podem retornar a seus países de origem devido a conflitos violentos ou desastres naturais. 
Proposto em 2014, na segunda gestão do presidente Barack Obama, o programa Deferred Action for Parents of Americans and Lawful Permanent Residents (DAPA) tinha como objetivo estender a proteção temporária contra a deportação a imigrantes indocumentados que tivessem tido filhos nos EUA, bem como permitir que requisitassem o pedido de visto temporário de trabalho. No entanto, em fevereiro de 2016, o juiz do Tribunal Distrital dos Estados Unidos Andrew S. Hanen concedeu liminar, a pedido do Texas e com a adesão de outros 25 estados, para suspender a implementação do DAPA. Os estados argumentavam que o programa representava "uma mudança significativa na lei de imigração instituída unilateralmente pelo Poder Executivo, em violação à doutrina da separação de poderes e à cláusula Take Care da Constituição" (Wood, 2017, p. 30). Antes de se pronunciar favoravelmente ao Texas e aos demais estados, Hanen havia criticado a política migratória de Obama. O programa DAPA poderia beneficiar 4 milhões dos cerca de 11 milhões de imigrantes indocumentados que vivem nos Estados Unidos. Mas, devido aos questionamentos judiciais, nunca entrou em vigor (Volpp, 2019).

Em junho de 2016, com a Suprema Corte dividida, o julgamento empatado em $4 \times 4$, a vacância de um membro, devido à morte do juiz Antonin Scalia, e a recusa do Senado, dominado pelos republicanos, de confirmar a indicação do presidente Obama para a Corte, a decisão do juiz Hanen foi mantida e o DAPA, bloqueado.

Sem a proteção prevista no programa, o drama das famílias é que elas precisam decidir se partem para seus países de origem (na grande maioria dos casos, na América Central e no México) com ou sem os filhos - amparados pelo DACA. A quebra do vínculo social e produtivo nos EUA é brutal. Primeiro porque a remessa de dinheiro dos EUA para os familiares desses imigrantes, em seus países de origem, quase sempre é a única renda que assegura a sobrevivência destes. Segundo porque retornar sem renda a países mergulhados em conflitos e pobreza torna o destino dessas pessoas incerto. Respondendo a críticas generalizadas à separação familiar, o presidente Trump emitiu em 20 de junho de 2018 a Executive Order 13841, intitulada Affording Congress an Opportunity to Address Family Separation. A ordem instruía o Department of Homeland Security a manter a custódia de pais e filhos em conjunto, na medida em que isso fosse legalmente possível, e sujeito à disponibilidade de dotações.

Finalmente, destacamos a P.P. 9931, Suspension of Entry as Immigrants and Nonimmigrants of Persons Responsible for Policies or Actions That Threaten Venezuela's Democratic Institutions, emitida em 25 de setembro de 2019, que apesar de não restringir a imigração de todo o povo venezuelano, proibiu a entrada, nos Estados Unidos, de membros sêniores do governo de Nicolás Maduro.

Com efeito, na edição de medidas unilaterais, Trump deu seguimento ao movimento de securitização da imigração latino-americana iniciado em seus atos discursivos. A estratégia discursiva de categorização dos mexicanos como criminosos expressa na SD2 também foi empregada para categorizar os estrangeiros nas medidas unilaterais, conforme o Quadro 4:

QUADRO 4 - Categorização dos imigrantes da fronteira-sul nas medidas unilaterais

\begin{tabular}{l|l}
\hline Medida unilateral & \multicolumn{1}{c}{ Categorização } \\
\hline P.P. 9844 & $\begin{array}{l}\text { "The Southern border is a major entry point for criminals, gang members, } \\
\text { and illicit narcotics" }\end{array}$ \\
\hline E.O. 13767 & $\begin{array}{l}\text { "Transnational criminal organizations operate sophisticated drug-and } \\
\text { human-trafficking networks and smuggling operations on both sides of } \\
\text { the Southern border" }\end{array}$ \\
\hline E.O.13768 & $\begin{array}{l}\text { "Many of these aliens are criminals who have served time in our Federal, } \\
\text { State, and local jails." }\end{array}$ \\
\hline E.O. 13841 & $\begin{array}{l}\text { "When an alien enters or attempts to enter the country anywhere else, } \\
\text { that alien has committed at least the crime of improper entry and is } \\
\text { subject to a fine or imprisonment" }\end{array}$ \\
\hline
\end{tabular}

Fonte: elaborado pelos autores a partir de dados coletados no American Presidency Project. 
As executive orders 13767 e 13768 foram justificadas a partir da perspectiva de que os imigrantes representavam uma ameaça significativa à segurança nacional e à segurança pública. Já a Executive Order 13788 e as presidential proclamations 9822, 9842, 9844, 9880 e 9931 foram fundamentadas na defesa do interesse nacional. Ambas as justificativas estão em conformidade com o binômio "eu-outro" que fundamenta a perspectiva conservadora de Huntington e as teorias da Escola de Copenhague, do construtivismo e da Análise Crítica do Discurso.

\section{O movimento de securitização da imigração muçulmana}

Embora a islamofobia remonte às visões orientalistas do mundo árabe produzidas pelo Ocidente desde o século VII, o termo ganhou proeminência nos Estados Unidos após os atentados de 11 de setembro de 2001. No campo teórico, a islamofobia estaria relacionada ao conceito de "extremismo islâmico" desenvolvido no "choque de civilizações" de Huntington (Bazian, 2018). Durante as primárias do Partido Republicano e a campanha eleitoral, e mesmo após eleito, Trump proferiu uma série de discursos anti-islâmicos que permitiram a construção de uma retórica da ameaça associada aos muçulmanos.

Após o presidente Obama fazer um a pelo por tolerância e solidariedade em relação aos muçulmanos, e diferenciar a guerra contra o terrorismo do Islã, no contexto dos ataques de San Bernardino, ${ }^{9}$ Trump delineou sua proposta conhecida como Muslim Ban, que consiste na proibição da entrada de muçulmanos nos EUA. Em seu discurso, Trump construiu uma narrativa polarizadora ("nós" contra "eles"), em que associou os muçulmanos a termos negativos como ódio, terrorismo, radicalização e extremismo, e direcionou negativamente componentes islâmicos como Shariah e Jihad. Em sua representação, prejudicial ao Islã, a maioria das crenças muçulmanas é representada como anti-mulher e antiamericana, ameaçando a segurança dos Estados Unidos e seu modo de vida (Khan et al., 2019).

Em decorrência do massacre ocorrido na boate LGBT Pulse, em Orlando, em junho de 2016, e reivindicado pelo grupo Estado Islâmico do Iraque e do Levante, o presidente Trump delineou, em um discurso em New Hampshire, o objetivo de sua proposta de política migratória:

SD4 [Estratégia discursiva]

1. We have to stop the tremendous flow of Syrian refugees into the United States [Expressão normativa]

2. - we don't know who they are, [Categorização]

3. they have no documentation, [Categorização e Generalização]

4. and we don't know what they're planning. [Contrafactual e Implicação]

5. What I want is common sense. [Expressão normativa e Consenso]

6. I want a mainstream immigration policy that promotes American values. [Expressão normativa e Autoglorificação nacional]

Na SD4 prevalece, mais uma vez, a lógica do embate, com os refugiados sírios tendo seu comportamento categorizado e generalizado. Trump faz insinuações sobre supostos planos dos refugiados e expressa a intenção de interromper o fluxo de sua entrada nos EUA. Utilizando a primeira pessoa do singular, Trump expressa para a audiência que sua proposta de política migratória é consensual, uma vez que promove valores americanos, em um claro apelo à autoglorificação nacional. Com efeito, ao apelar aos valores americanos

\footnotetext{
No dia 2 de dezembro de 2015, dois atiradores mataram catorze americanos em um tiroteio em massa em San Bernardino, Califórnia. De acordo com o Federal Bureau of Investigation (FBI), os assassinos eram um casal muçulmano-americano de origem paquistanesa.
} 
para delinear sua proposta de política migratória, Trump recorre à ideologia conservadora no sentido delineado por Huntington (1997a), isto é, na ideia de que o credo americano originado com os founding fathers deve ser preservado. Na narrativa de Trump, os valores americanos são ameaçados pelo islamismo radical:

SD5 [Estratégia discursiva]

1. Many of the principles of Radical Islam are incompatible with Western values and institutions. [Comparação e Polarização]

2. Radical Islam is anti-woman, anti-gay and anti-American. [Categorização]

3. I refuse to allow America to become a place where gay people, Christian people, and Jewish people, are the targets of persecution and intimidation by Radical Islamic preachers of hate and violence. [Expressão normativa e Polarização]

4. It's not just a national security issue. It is a quality of life issue. [Expressão normativa e Autoglorificação nacional]

Assim como na SD4, na SD5 Trump enfatiza aspectos positivos sobre "nós" e enfatiza aspectos negativos sobre eles. Categoriza, compara e polariza os valores ocidentais contra os princípios do islamismo radical. Em seguida, expressa-se uma condenação desses princípios. Para Trump, não se trata apenas de uma questão de segurança nacional, mas de defesa do American way of life. Para enfrentar essa ameaça, o então candidato sugeria:

SD6 [Estratégia discursiva]

1. The male shooter in San Bernardino-again, whose name I won't mention-was the child of immigrants from Pakistan, and he brought his wife-the other terrorist-from Saudi Arabia, through another one of our easily exploited visa programs. [Evidencialidade e Vitimização]

2. Immigration from Afghanistan into the United States has increased nearly five-fold in just one year. [Jogo de números]

3. According to Pew Research, 99\% of people in Afghanistan support oppressive Sharia Law. [Jogo de números, Categorização e Generalização]

4. We admit many more from other countries in the region who share these same oppressive views. [Evidencialidade, Categorização e Generalização]

5. If we want to remain a free and open society, then we have to control our borders. [Consenso e Expressão normativa]

Na SD6 Trump apela à evidencialidade e ao jogo de números para categorizar e generalizar os comportamentos e as visões de mundo dos imigrantes do Oriente Médio. Em sua narrativa, os Estados Unidos seriam uma vítima de seus próprios programas de visto aos estrangeiros, que teriam permitido a entrada do casal de atiradores de San Bernardino. Trump posiciona-se contrariamente também ao crescimento da imigração afegã e de outros países da região, cujos nacionais sustentariam, segundo ele, visões opressivas. Apelando ao medo da audiência, Trump expressa sua proposta de controlar as fronteiras para que os EUA permaneçam uma sociedade livre e aberta. No dia anterior a esse discurso, conforme a SD7, Trump já havia apelado à vitimização em sua conta no Twitter:

SD7 [Estratégia discursiva]

1. What has happened in Orlando is just the beginning. [Pressuposto, Vagueza e Vitimização]

2. Our leadership is weak and ineffective. [Vitimização]

3. I called it and asked for the ban. Must be tough. [Expressão normativa]

Considerando a liderança dos EUA fraca e ineficaz, Trump expressa, na SD7, a proposta de banimento da entrada de imigrantes (muçulmanos) nos EUA. De acordo com Marietta et al. (2017), durante a campanha eleitoral, Trump empregou a retórica da ameaça no Twitter com mais intensidade que seus rivais republicanos e que Hillary Clinton. Contudo, sua retórica anti-muçulmana não se restringe às mídias sociais. Em entrevista à Fox Business, 
Trump considerou a possibilidade de fechar mesquitas nos EUA. Em seu discurso inaugural como presidente, ele foi além (SD8). Mobilizando uma retórica polarizadora, prometeu:

SD8 [Estratégia discursiva]

1. We will reinforce old alliances and form new ones [Expressão normativa e Consenso]

2. and unite the civilized world against radical Islamic terrorism, which we will eradicate completely from the face of the Earth. [Expressão normativa, Polarização e Metáfora]

Também na SD8, Trump operou a lógica do embate polarizador, opondo o islamismo radical aos EUA e seus aliados. Enquanto este último grupo é identificado por Trump como civilized world, o islamismo radical é associado ao terrorismo e, enquanto tal, algo que deveria ser erradicado da face da terra. Desse modo, Trump expressa que não há convivência possível com a alteridade, e que esta deve ser completamente eliminada.

Assim que tomou posse como presidente dos Estados Unidos, Donald Trump atuou para securitizar a questão da imigração muçulmana por meio da edição de duas executive orders e três presidential proclamations. Nomeada Protecting the Nation From Foreign Terrorist Entry Into the United States, a Executive Order 13769, de 27 de janeiro de 2017, visava criar novas medidas para impedir terroristas radicais islâmicos de entrar nos EUA. Embora não impedisse diretamente a entrada de muçulmanos no país, a medida proibia, por noventa dias, a entrada de cidadãos de países de maioria muçulmana como lêmen, Iraque, Irã, Líbia, Somália, Sudão e Síria. Suspendia, ainda, a entrada de refugiados sírios por tempo indeterminado e de refugiados vindos de qualquer país por 120 dias.

Alvo de intensa controvérsia judicial, a Executive Order 13769 teve sua execução proibida em grande parte por tribunais federais, que a consideraram inconstitucional, já que discriminava os muçulmanos por razões religiosas. Visando blindar a medida de contestações legais, o presidente a revogou e a substituiu pela Executive Order 13780, em 6 de março de 2017. A nova medida, apelidada travel ban 2.0, manteve a proibição, por noventa dias, da entrada de cidadãos do mesmo grupo de países, com exceção do Iraque, retirado. Ademais, relaxou restrições à entrada de refugiados sírios e excluiu da proibição portadores de green card e cidadãos com visto. Por outro lado, a medida suspendeu ${ }^{10}$ por 120 dias o Programa de Admissão de Refugiados dos EUA. No dia seguinte à edição do travel ban 2.0, o estado do Havaí ajuizou uma ação civil contrária à medida. Oito dias depois, o juiz distrital Derrick Watson emitiu uma ordem de restrição temporária impedindo que as seções 2 e 6 da Executive Order 13780 entrassem em vigor. A decisão foi confirmada parcialmente pelo painel do Ninth Circuit.

Com o intuito de eliminar o viés religioso, o presidente Donald Trump emitiu em 24 de setembro de 2017 a Presidential Proclamation 9645, chamada oficialmente de Proclamation on Improving Enhanced Vetting Capabilities and Processes for Detecting Attempted Entry - e, informalmente, de travel ban 3.0. A medida do Executivo retirou o Sudão da lista de países atingidos pelo travel ban 2.0 e adicionou cidadãos do Chade, da Coreia do Norte e da Venezuela. Também contestado judicialmente pelo estado do Havaí, o veto sofreu ordem de restrição temporária da Justiça Federal. Em ação ajuizada pela American Civil Liberties Union's Immigrants' Rights Project, a Justiça Federal considerou que os comentários públicos do presidente Trump sugeriam que a segurança nacional não seria o objetivo principal do travel ban. Determinou, ainda, que o governo federal não poderia impor a pessoas dos países mencionados a proibição de viajar por motivos de preferências religiosas, e manteve o veto a cidadãos da Coreia do Norte e da Venezuela.

Todavia, em dezembro de 2017, a Suprema Corte revogou liminarmente as decisões de tribunais inferiores contra o presidente, permitindo que o travel ban fosse efetivado enquanto os casos não fossem julgados (Pierce et al., 2018). Revisões adicionais foram

\footnotetext{
${ }^{10}$ O Programa de Admissão de Refugiados foi retomado na Executive Order 13815, de 24 de outubro de 2017. Já a Executive Order 13888, de 26 de setembro de 2019, condicionou o reassentamento de refugiados ao consentimento de estados e localidades. Apesar de tratar de temática correlata à imigração, as medidas não foram incluídas no corpus do Quadro 3 por não mencionar especificamente latinos e muçulmanos.
} 
realizadas por meio de outras duas medidas. Em abril de 2018, a Presidential Proclamation 9723 removeu as restrições aos cidadãos do Chade. Em 2020, a Presidential Proclamation 9983 incluiu na lista de restrições cidadãos da Eritreia, Quirguistão, Myanmar, Nigéria, Tanzânia e, novamente, do Sudão. Antes desta última medida, em 26 de junho, contudo, a Suprema Corte já havia decidido, definitivamente, por 5 a 4, pela legalidade do travel ban.

Assim como fez com a Venezuela, Trump editou, em 25 de setembro de 2019, a Presidential Proclamation 9932, suspendendo a entrada de membros sêniores do governo iraniano. Trump argumentou na medida que o governo do Irã é um Estado patrocinador do terrorismo, que o Irã detém arbitrariamente cidadãos americanos, e que o regime iraniano contribui para crises humanitárias, ameaça seus vizinhos e a navegação internacional e conduz ataques cibernéticos destrutivos.

Com efeito, o movimento de securitização da imigração muçulmana realizado por Donald Trump e expresso na retórica da ameaça e na edição de medidas executivas teve como objetivo aumentar a fiscalização e impor restrições à imigração legal, de forma a impedir a entrada de pessoas consideradas ameaças à segurança pública e a garantir o compartilhamento de informações de governos estrangeiros sobre seus cidadãos com os Estados Unidos. No escopo das medidas promulgadas para o muslim ban, o presidente suspendeu o Visa Interview Waiver Program, que permitia que alguns viajantes renovassem suas autorizações de viagem sem uma entrevista pessoal. A necessidade de comparecimento a uma entrevista pessoal foi estendida também a solicitantes de residência permanente com base em vínculos empregatícios.

As medidas unilaterais ampliaram também a verificação, aumentando a quantidade de informações que os solicitantes de visto devem fornecer. Nesse sentido, refugiados de países considerados de "alto risco" que solicitam reassentamento também ficaram sujeitos a medidas de rastreamento mais rigorosas, como entrevistas adicionais com familiares. Por fim, em fevereiro de 2018, o presidente emitiu um memorando ordenando a criação de um centro nacional de verificação, que visava simplificar o processo de verificação de imigração.

Para dar seguimento ao movimento de securitização da imigração muçulmana, Trump editou medidas unilaterais em conformidade com seus atos discursivos. Empregando as estratégias discursivas da evidencialidade e da categorização, suas medidas unilaterais associam estrangeiros egressos de países islâmicos e filhos de imigrantes islâmicos nascidos nos EUA ao terrorismo, conforme o Quadro 5:

QUADRO 5 - Categorização dos imigrantes de países islâmicos e de filhos de imigrantes nascidos nos Estados Unidos nas medidas unilaterais:

\begin{tabular}{l|l}
\hline Medida unilateral & \multicolumn{1}{c}{ Categorização } \\
\hline E.O.13769 & $\begin{array}{l}\text { "Numerous foreign-born individuals have been convicted or implicated } \\
\text { in terrorism-related crimes since September 11, 2001, including foreign } \\
\text { nationals who entered the United States after receiving visitor, student, } \\
\text { or employment visas, or who entered through the United States refugee } \\
\text { resettlement program." }\end{array}$ \\
\hline E.O.13780 & $\begin{array}{l}\text { "Since 2001, hundreds of persons born abroad have been convicted of } \\
\text { terrorism-related crimes in the United States. They have included not } \\
\text { just persons who came here legally on visas but also individuals who first } \\
\text { entered the country as refugees." }\end{array}$ \\
\hline P.P. 9456 & $\begin{array}{l}\text { "Despite those efforts, the Secretary of Homeland Security, in } \\
\text { consultation with the Secretary of State and the Attorney General, } \\
\text { has determined that a small number of countries-out of nearly 200 } \\
\text { evaluated-remain deficient at this time with respect to their identity- } \\
\text { management and information-sharing capabilities, protocols, and } \\
\text { practices. In some cases, these countries also have a significant terrorist } \\
\text { presence within their territory." }\end{array}$ \\
\hline
\end{tabular}

Fonte: elaborado pelos autores a partir de dados coletados no American Presidency Project.

Assim como no caso da imigração latino-americana, Trump deu continuidade, com a edição de medidas unilaterais, ao movimento de securitização da imigração muçulmana 
iniciado em seus atos discursivos. As executive orders 13769 e 13780 e as presidential proclamations 9645, 9723 e 9983 foram justificadas a partir da perspectiva de que os imigrantes representavam uma ameaça significativa à segurança nacional e à segurança pública. Por sua vez, a Presidential Proclamation 9932 foi fundamentada na defesa do interesse nacional. Mais uma vez, ambas as justificativas estão em conformidade com o debate teórico delineado.

\section{Legitimação e veto players na política migratória de Trump}

Em sua campanha eleitoral, Trump mobilizou retóricas da ameaça associadas aos setores militar, econômico e societal. A percepção de ameaça à segurança pessoal foi construída a partir da narrativa da criminalidade associada a imigrantes indocumentados e da violência terrorista. A imigração foi invocada também como uma ameaça ao status socioeconômico (quando associada à desvalorização salarial e perda de empregos) e ao status de grupo (no aspecto identitário cultural).

Com efeito, Trump construiu uma retórica de estilo absolutista, enfatizando fronteiras não negociáveis e indignação moral, o que resultou em sua vitória eleitoral (Marietta et al., 2017). No governo, buscou securitizar a questão migratória com executive orders e presidential proclamations. $\mathrm{O}$ enfrentamento às ameaças percebidas envolveu mudanças na política migratória dos Estados Unidos, com um endurecimento em relação à imigração indocumentada e restrições à imigração legal.

A retórica da ameaça e as ações políticas do presidente Donald Trump constituem o movimento de securitização da imigração latino-americana e muçulmana, mas não criam, por si só, essa securitização. Ela só se completa na medida em que a audiência do agente securitizador aceita o movimento nos termos construídos. Desse modo, a securitização não é imposta pelo agente. Sua legitimação advém da aceitação, pelos atores funcionais, da narrativa construída pelo agente. Atores funcionais afetam a dinâmica de um setor ao influenciar significativamente as decisões tomadas pelos agentes (Buzan et al., 1998). No setor societal, a opinião pública cumpre este papel, na medida em que atua como porta-voz dos valores da identidade coletiva.

De acordo com os dados disponíveis no Polling Report (2020), pesquisas de opinião pública têm demonstrado, desde o início da administração Trump, que o movimento de securitização da imigração não foi completamente legitimado. A esse respeito, pesquisa da Quinnipiac University de julho de 2019 mostrou que 70\% da opinião pública sustentava uma visão positiva sobre a imigração no país. Todavia, essa avaliação variou consideravelmente de acordo com a inclinação partidária do entrevistado. Enquanto $87 \%$ dos democratas e $75 \%$ dos independentes consideravam a imigração positiva, apenas $49 \%$ dos republicanos tinham a mesma visão. A pesquisa apontou, ainda, que $86 \%$ dos democratas consideravam os centros de detenção de imigrantes desumanos, enquanto 70\% dos republicanos tinham uma percepção oposta.

A opinião pública também se dividiu em relação aos objetos de referência específicos da administração Trump, isto é, a imigração latina e muçulmana. Em pesquisa da Monmouth University de abril de 2019,56\% dos entrevistados se opunham à construção de um muro na fronteira com o México, ao passo que $42 \%$ apoiavam a medida. Pesquisa realizada pela $A B C$ News e o Washington Post no mesmo mês mostrou que $64 \%$ dos entrevistados se opunham à declaração de emergência nacional usada por Trump para aplicar fundos federais à construção de um muro na fronteira. Essa divisão está presente também em relação à permissão da entrada de refugiados centro-americanos nos EUA. De acordo com pesquisa do Gallup de julho de 2019, 57\% da opinião pública aprova a acolhida aos refugiados, enquanto $39 \%$ desaprovam. 
No que se refere aos muçulmanos, pesquisa da Quinnipiac University de fevereiro de 2017 revelou que 51\% dos americanos consideravam que a Executive Order 13769 do governo Trump visava impor uma proibição à sua entrada nos EUA. Em pesquisa do Pew Research Center, realizada no mesmo mês, 78\% dos entrevistados se diziam muito informados a respeito da medida. Em março de 2017, pesquisa da McClatchy-Marist apontava uma divisão da opinião pública em relação à medida: $52 \%$ dos entrevistados se opunham e $43 \%$ a apoiavam. A divisão se mantinha um ano depois, quando uma pesquisa da Quinnipiac University mostrou 49\% de aprovação em relação à decisão da Suprema Corte de permitir o travel ban, e $46 \%$ de reprovação. É interessante observar, também, que a opinião pública se dividiu em pesquisa da CNN/ORC, de fevereiro de 2017, quanto à avaliação de que a Executive Order 13769 protegia os valores americanos. Enquanto $43 \%$ consideravam que ela os protegia, $47 \%$ achavam que ela os prejudicava.

Com efeito, as pesquisas sinalizam que os movimentos de securitização implementados pelo governo Trump foram legitimados apenas por republicanos e apoiadores, e rejeitados pela maioria da opinião pública, que tende a sustentar uma visão positiva sobre imigração. Nesse ambiente polarizado, o presidente teria incentivos significativos para dobrar sua retórica sobre a restrição da imigração (Pierce et al., 2018), enquanto o Congresso, o Judiciário e os governos estaduais e locais eram incentivados a agir como veto players. Assim como a opinião pública, o comportamento partidário no Legislativo tem sido diagnosticado como mais polarizado, sobretudo desde o fim da Guerra Fria (Poole e Rosenthal, 1997, 2007; Ragusa, 2016). Embora moderada, essa polarização tem atingido também a temática da imigração, sobretudo na House of Representatives, evitando que legislações relacionadas a ela cheguem ao Senado (Contrera, 2017).

Ao mobilizar a retórica da ameaça para construir um movimento de securitização da imigração, o presidente Trump polarizou ainda mais a discussão em torno dessa temática, inviabilizando a aprovação de uma reforma migratória ampla no Legislativo. Mesmo no primeiro biênio do mandato de Trump, quando o Partido Republicano detinha o controle da maioria nas duas casas do Congresso, a reforma migratória não avançou. Em fevereiro de 2018, o Senado rejeitou quatro propostas de reforma migratória, entre as quais a do senador Chuck Grassley (R-lowa), que reunia os quatro pilares da reforma da imigração anunciados no discurso inaugural do governo Trump. As eleições legislativas de 2018 deram ao Partido Democrata o controle da House of Representatives, instituindo um ponto de veto e inviabilizando a aprovação de uma ampla reforma migratória por mudança na legislação durante o mandato de Donald Trump. Contrariamente ao presidente, o Congresso aprovou, em fevereiro de 2019, uma legislação (H.J.Res.46) para derrubar a declaração de emergência nacional para financiar a construção de um muro na fronteira sul.

Governos estaduais e municipais têm atuado também como importantes pontos de veto à implementação das políticas migratórias executadas por Trump. Embora a regulação da imigração seja responsabilidade do governo federal, sua implementação depende de cooperação intergovernamental entre a agência federal de imigração (ICE) e os demais entes federativos. A cooperação é fundamental para que a ICE possa levar imigrantes ilegais residentes nas localidades à prisão e, posteriormente, deportá-los. O estado do Texas, por exemplo, é um caso emblemático de cooperação, já que exige que as agências policiais locais cumpram as ordens de detenção da ICE. Em contrapartida, um número crescente de governos estaduais e municipais promulgou políticas de "santuário", que proíbem policiais e agentes penitenciários de cumprir as determinações. $\bigcirc$ exemplo mais notório desse caso é o estado da Califórnia, que obteve uma vitória judicial sobre o governo federal.

Finalmente, o Judiciário tem desempenhado um papel importante para atenuar ou restringir os efeitos da política migratória de Donald Trump. Em decorrência da intensa judicialização e da imposição de uma sucessão de derrotas ao governo nos tribunais federais, a administração Trump modificou reiteradas vezes sua política de travel ban, 
inicialmente caracterizada como uma proibição de entrada nos Estados Unidos de cidadãos de países majoritariamente muçulmanos. A proibição motivada por motivos religiosos, considerada inconstitucional, foi posteriormente descaracterizada pela presidência, que estendeu o veto a países não muçulmanos associados ao terrorismo pelos americanos, como Coreia do Norte e Venezuela.

Desse modo, o movimento de securitização da imigração construído pela administração Trump foi incompleto. Não conseguiu criar consenso na opinião pública e nem tampouco no Legislativo. A recusa de governos estaduais e locais de implementar determinadas ações e as restrições estabelecidas pelo Judiciário atuaram contrariamente ao movimento. Como as mudanças na política migratória dos Estados Unidos efetuadas pelo governo foram conduzidas unilateralmente pelo Executivo, elas estão sujeitas à imediata revogação por Biden. A intensificação da polarização ideológica, que se reflete na opinião pública, no Legislativo e em decisões divididas na Suprema Corte, contribui para a descontinuidade da política de imigração, cujas prioridades e orientações alteram-se sempre que há mudança no controle do Executivo.

Apesar disso, o governo Trump persistiu na construção tanto de um muro físico quanto de um muro legal contra a imigração. A partir da crise sanitária da Covid-19 as restrições à entrada de imigrantes foram intensificadas. ${ }^{11}$ A derrota de Trump nas eleições de 2020, contudo, apontava para a reversão de sua política migratória.

\section{Considerações finais}

As políticas migratórias são particularmente politizadas porque envolvem percepções ligadas tanto à identidade nacional como à maneira como a sociedade se relaciona com o exterior. Nesse sentido, representam posicionamentos que buscam conciliar contextos externos e a coesão interna, dentro de um equilíbrio frágil e bastante suscetível a distúrbios. Por isso mesmo, mudanças nos comportamentos sociais - como uma maior aceitação do multiculturalismo e da diversidade - acabam se refletindo em novas posturas em relação à imigração e, por sua vez, em novas políticas migratórias que nem sempre coadunam com aquelas que já existem.

Novas políticas migratórias geralmente contradizem as políticas anteriores e comprometem seus objetivos. As emendas à Lei de Imigração e Naturalização de 1965, também chamada Lei Hart-Celler, estabeleceram um sistema de emissão de vistos de residentes permanentes com base sobretudo em vínculos familiares ou empregatícios. A maioria das mudanças na política de imigração dos EUA desde então envolveu alterações nas margens deste sistema, mas não produziu nenhuma reformulação mais ampla. O resultado é um conjunto incoerente de leis e de regulamentos. A relutância do Executivo estadunidense em confrontar decisões politicamente difíceis é um fator que contribui para o fracasso em elaborar leis que possam resistir ao teste do tempo (Orrenius e Zavodny, 2017).

O enfrentamento da questão migratória, contudo, não deve mobilizar movimentos de securitização. Embora esta estratégia tenha sido eficaz para Trump no contexto eleitoral, ela se mostra ineficiente na construção de um arcabouço legal de longo prazo. A securitização transforma o imigrante em ameaça. É uma retórica opressora e excludente, que fomenta o ódio ao "outro" e desvia o foco dos problemas mais urgentes relacionados à imigração.

\footnotetext{
11 As presidential proclamations de números 9984, 9992, 9993, 9996, 10014, 10041, 10042, 10052 e 10131 suspenderam a entrada de imigrantes e não-imigrantes nos EUA em face do risco de transmissão da doença e para evitar a concorrência de estrangeiros no mercado de trabalho em meio à crise econômica gerada pela pandemia. Nos últimos dias de mandato, Trump determinou o fim da suspensão de entrada nos Estados Unidos de estrangeiros que tivessem estado no Espaço de Schengen, no Reino Unido, na Irlanda e no Brasil (PP. 10138).
} 
Para reformar a política migratória nos EUA é necessária a construção de um consenso mínimo, que deve estar assentado no respeito aos direitos humanos.

Medidas unilaterais do Executivo, como executive orders e presidential proclamations não são, portanto, o meio para realizar uma ampla reforma na política migratória - que, no limite, não visa apenas garantir as regras de aceitação do imigrante como parte da sociedade, mas é também um instrumento de inclusão do estrangeiro dentro da construção de uma identidade nacional. O futuro da política migratória nos Estados Unidos depende fortemente de uma reforma construída no Legislativo - algo que, por sua vez, demanda compromisso e algum grau de consenso entre democratas e republicanos. A imigração é, definitivamente, uma questão politizada que demanda da sociedade a construção de consensos, e não de muros.

\section{Agradecimentos}

Esta pesquisa foi desenvolvida com o apoio da Fundação de Amparo à Pesquisa do Estado de São Paulo (Processo FAPESP número 2019/20181-6) e da Fundação de Apoio à Pesquisa do Distrito Federal (Processo FAPDF número 798/2019). Agradecemos também aos pareceristas anônimos da RBCS pelos valiosos comentários.

\section{Contribuição dos autores}

Os autores abaixo relacionados participaram efetivamente na elaboração do manuscrito Retórica da ameaça e securitização: A política migratória dos Estados Unidos na administração Trump.

Segue abaixo, a descrição sobre as especificidades em cada etapa.

\section{Estruturação do desenho de pesquisa:}

Flávio Contrera

Karina Lilia Pasquariello Mariano

Roberto Goulart Menezes

2. Coleta, metodologia e análise de dados:

Flávio Contrera

Karina Lilia Pasquariello Mariano

Roberto Goulart Menezes

3. Redação, revisão e padronização do texto de acordo com as normas da revista:

Flávio Contrera

Karina Lilia Pasquariello Mariano

Roberto Goulart Menezes

\section{Bibliografia}

ACKLESON, Jason. (2005), "Constructing security on the US-Mexico border". Political Geography, 24, 2: 165-184.

ADAMSON, Fiona. (2006), "Crossing Borders: International Migration and National Security". International Security, 31, 1: 165-199.

ARMENDARES, Pedro. (2018), La política migratória de Trump. Impactos para los migrantes mexicanos y sus comunidades. Cidade do México, Instituto Belisario Domínguez. 
BALZACQ, Thierry. (2011), Enquiries into methods: a new framework for securitization analysis. In BALZACQ, Thierry (ed). Securitization Theory. How security problems emerge and dissolve. Abingdon, Routledge.

BAZIAN, Hatem. (2018), "Islamophobia, 'Clash of Civilizations', and Forging a Post-Cold War Order!". Religions, 9: 1-13.

BUZAN, Barry. (2004), The United States and the Great Powers. World Politics in the TwentyFirst Century. Cambridge, Polity Press.

BUZAN, Barry \& HANSEN, Lene. (2012), A evolução dos estudos de segurança internacional. São Paulo, Unesp.

BUZAN, Barry; WAEVER, Ole \& WILDE, Jaap. (1998), Security. A new framework for analysis. Colorado, Lynne Rienner Publishers.

CAPETILLO-PONCE, Jorge. (2007), "From 'A Clash of Civilizations' to 'Internal Colonialism': Reactions to the Theoretical Bases of Samuel Huntington's 'The Hispanic Challenge'". Ethnicities, 7, 1: 116-134.

CHOUCRI, Nazli. (2002), "Migration and Security: Some Key Linkages". Journal of International Affairs, 56, 1: 97-122.

CONTRERA, Flávio. (2017), Política externa americana no pós-Guerra Fria: como se posicionam democratas e republicanos? Tese de doutorado, Universidade Federal de São Carlos, São Carlos.

COSER, Lewis. (1956). The Functions of Social Conflict. Nova York, The Free Press.

DE LA GARZA, Rodolfo; FALCON, Angelo \& GARCIA, F. Chris. (1996), "Will the Real Americans Please Stand Up: Anglo and Mexican American Support of Core American Political Values". American Journal of Political Science, 40, 2: 335-351.

ETZIONI, Amitai. (2005). "The real threat: an essay on Samuel Huntington". Contemporary Sociology, 34, 5: 477-485.

FELDMAN, Stanley \& STENNER, Karen. (1997), "Perceived Threat and Authoritarianism". Political Psychology, 18, 4: 741-770.

FILOMENO, Felipe. (2020), "DACA e o elusivo sonho americano de jovens migrantes". Opeu, 17/06. Disponível em: https://www.opeu.org.br/2020/06/21/daca-e-o-elusivosonho-americano-de-jovens-imigrantes/. Consultado em 25/06/2021.

GHUGHUNISHVILI, Irina. (2010), Securitization of Migration in the United States after 9/11: Constructing Muslims and Arabs as Enemies. Tese de Doutorado. Central European University, Department of International Relations and European Studies, Budapeste, Hungria.

GREENHILL, Keely. (2018), "How Trump Manipulates the Migration Debate. The Use and Abuse of Extra-Factual Information". Foreign Affairs, Snapshot, 05/06.

HUNTINGTON, Samuel. (1997a), "The erosion of American national interests". Foreign Affairs, 76, 5: 28-49.

HUNTINGTON, Samuel. (1997b), O choque de civilizações e a recomposição da ordem mundial. Rio de Janeiro, Objetiva.

HUNTINGTON, Samuel. (2004), "The Hispanic Challenge". Foreign Policy, 141: 30-45.

HUTCHISON, Hugh. (2020), "Continuity and Change: Comparing the Securitization of Migration under the Obama and Trump Administrations". PERCEPTIONS: Journal of International Affairs, 25, 1: 81-98.

HUYSMANS, Jef. (2000), "The European Union and the Securitization of Migration". Journal of Common Market Studies, 39, 5: 751-777.

HUYSMANS, Jef. (2006), The Politics of Insecurity: Fear, Migration and Asylum in the EU. Londres, Routledge. 
JEFFERIS, Danielle. (2012), "Battlefield Borders, Threat Rhetoric, and The Militarization of State and Local Law Enforcement". National Security Law Brief, 3, 1: 37-73.

JEPPERSON, Ronald; KATZENSTEIN, Peter \& WENDT, Alexander. (1996), "Norms, Identity, and Culture in National Security". In: KATZENSTEIN, Peter (org.), The Culture of National Security: Norms and Identity in World Politics, Nova York, Columbia University Press.

KHAN, Mohsin; ADNAN, Hamedi; KAUR, Surinderpal; KHUHRO, Rashid; ASGHAR, Rohail \& JABEEN, Sahira. (2019), "Muslims' Representation in Donald Trump's Anti-MuslimIslam Statement: A Critical Discourse Analysis". Religions, 10, 2: 1-16.

KOUDELA, Pál. (2013). "A Brief History of Immigration Policy in the United States". West Bohemian Historical Review, 3, 2: 43-65.

LEBOWITZ, Lawrence \& PODHEISER, Ira. (2001), "A Summary of the Changes in Immigration Policies and Practices After the Terrorist Attacks of September 11, 2001: The USA Patriot Act and Other Measures". University of Pittsburgh Law Review, 63: 873-888.

LEE, Erika. (2002), "The Chinese exclusion example: Race, immigration, and American gatekeeping, 1882-1924". Journal of American Ethnic History, 21, 3: 36-62

LEUTERT, Stephanie. (2018), "The Migration Disconnect. Why Central Americans Will Keep on Heading to the United States". Foreign Affairs, Snapshot, 07/11.

MARIETTA, Morgan; FARLEY, Tyler; COTE, Tyler \& MURPHY, Paul. (2017), "The Rhetorical Psychology of Trumpism: Threat, Absolutism, and the Absolutist Threat". The Forum, 15, 2: 313-332.

MARTIN, Lisa. (1999). Democratic Commitments: Legislatures and International Cooperation. Cambridge University Press.

MEYNAUD, Hélène-Yvonne \& DUCLOS, Denis. (2007), Les sondages d'opinion. Paris, La Découverte.

MOE, Terry \& HOWELL, William. (1999). "The Presidential Power of Unilateral Action". Journal of Law, Economics, and Organization, 15, 1: 132-179.

MULLET, Dianna. (2018), "A General Critical Discourse Analysis Framework for Educational Research". Journal of Advanced Academics, 29, 2: 116-142.

ONREAT, Emma; HIEL, Alain van \& CORNELIUS, Ilse. (2013), "Threat and Right-Wing Attitude: A Cross-National Approach". Political Psychology, 34, 5: 791-803.

ORLANDI, Eni. (2012). Análise de Discurso: princípios e procedimentos. São Paulo, Pontes.

ORRENIUS, Pia \& ZAVODNY, Madeline.(2017), "Creating Cohesive, Coherent Immigration Policy". Journal on Migration and Human Security, 5, 1: 180-93.

PALLEY, Thomas. (2017), "Trump's Neocon Neoliberalism Camouflaged with AntiGlobalization Circus". Challenge, 60, 4: 368-374.

PARRADO, Emílio \& MORGAN, S. Philip. (2008), "Intergenerational fertility among Hispanic women: new evidence of immigrant assimilation". Demography, 45, 3: 651-671.

PETRIGLIERI, Jennifer. (2011), "Under Threat: Responses to and the Consequences of Threats to Individuals' Identities". Academy of Management Review, 36, 4: 641-662.

PERNI, Orrieta. (2001). "Migration Flows, Societal Security and EU's Integration Process. The Spanish Case". European Security in the XXI century, Workshop 7: Europe facing migration flows. Granada, 5-9/11.

PIERCE, Sarah; BOLTER, Jessica \& SEELE, Andrew. (2018), U.S. Immigration Policy Under Trump: Deep Changes and Lasting Impacts. Washington, Migration Policy Institute.

POLLING REPORT. (2020), "Immigration and Border Security". Disponível em www. pollingreport.com/immigration.htm, consultado em: 15/6/2021.

POOLE, Keith \& ROSENTHAL, Howard. (1997), Congress: A Political-Economic History of Roll Call Voting. Nova York, Oxford University Press. 
POOLE, Keith \& ROSENTHAL, Howard. (2007), Ideology and Congress. New Brunswick, Transaction Publishers.

RAGUSA, Jordan. (2016), "Partisan Cohorts, Polarization, and the Gingrich Senators". American Politics Research, 44, 2: 296-325.

SCHMID, Katharina \& MULDOON, Orla. (2015), "Perceived Threat, Social Identification, and Psychological Well-Being: The Effect of Political Conflict Exposure". Political Psychology, 36, 1: 75-92.

SIMMEL, Georg. (1904), "The Sociology of Conflict: I". American Journal of Sociology, 9, 4: 490-525.

SOMERVILLE, Will \& SUMPTION, Madeleine. (2009), Immigration and the Labour Market: Theory, Evidence and Policy. Washington, Migration Policy Institute.

SPENCER, Alexander. (2008), "Linking Immigrants and Terrorists: The Use of Immigration as an Anti-Terror Policy". The Online Journal of Peace and Conflict Resolution, 8, 1: 1-24.

STIVACHTIS, Yannis. (2008), "International Migration and the Politics of Identity and Security". Journal of Humanities and Social Sciences, 2, 1: 1-24.

TELLES, Edward. (2006), "Os mexicanos-americanos e a nação americana: resposta ao professor Huntington". Tempo Social, 18, 2:167-184.

VAN DIJK, Teun. (2006), "Discourse and manipulation". Discourse \& Society, 17: 359-83.

VAZ, Celso Antônio Coelho. (2014), "The Americano Dream ou The American Dream: o debate contemporâneo sobre a imigração de mexicanos para os Estados Unidos". Opinião Pública, 20, 3: 496-522.

VEREA, Mónica. (2018), "Anti-Immigrant and Anti-Mexican Attitudes and Policies during the First 18 Months Of the Trump Administration". Norteamérica, 13, 2: 197-226.

VOLPP, Leti. (2019). "DACA, DAPA, and Discretionary Executive Power: Immigrants Outside the Law". California Journal of Politics and Policy, 11, 2: 1-20.

WAEVER, Ole. (1993), "Societal Security: The Concept". In: WAEVER, Ole; BUZAN, Barry; KELSTRUP, Morten \& LEMAITRE, Pierre (orgs). Identity, Migration and the New Security Agenda in Europe. Londres, Pinter Publishers.

WAEVER, Ole. (1995), "Securitization and Desecuritization". In: LIPSCHUTZ, Ronnie (org.), On Security, Nova York, Columbia University Press.

WATERS, Mary \& JIMENEZ, Tomas. (2005), "Assessing immigrant assimilation: New empirical and theoretical challenges". Annual Review of Sociology, 31: 105-125.

WEINER, Myron. (1992), "Security, Stability, and International Migration". International Security, 17, 3: 91-126.

WENDT, Alexander. (1999). Social Theory of International Politics. Cambridge University Press.

WOOD, Robert H. (2017), "The Crushing of a Dream: DACA, DAPA and the Politics of Immigration Law Under President Obama". Barry Law Review, 22, 1: 27-45. 